\title{
Aerosol composition, sources and processes during wintertime in Beijing, China
}

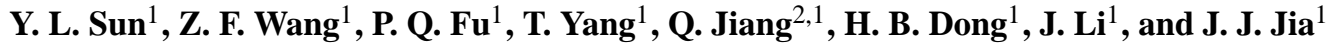 \\ ${ }^{1}$ State Key Laboratory of Atmospheric Boundary Layer Physics and Atmospheric Chemistry, Institute of Atmospheric \\ Physics, Chinese Academy of Sciences, Beijing 100029, China \\ ${ }^{2}$ Key Laboratory for Aerosol-Cloud-Precipitation of China Meteorological Administration, Nanjing University of Information \\ Science \& Technology, Nanjing 210044, China
}

Correspondence to: Y. L. Sun (sunyele@mail.iap.ac.cn)

Received: 14 December 2012 - Published in Atmos. Chem. Phys. Discuss.: 21 January 2013

Revised: 25 March 2013 - Accepted: 12 April 2013 - Published: 2 May 2013

\begin{abstract}
Air pollution is a major environmental concern during all seasons in the megacity of Beijing, China. Here we present the results from a winter study that was conducted from 21 November 2011 to 20 January 2012 with an Aerodyne Aerosol Chemical Speciation Monitor (ACSM) and various collocated instruments. The non-refractory submicron aerosol $\left(\mathrm{NR}-\mathrm{PM}_{1}\right)$ species vary dramatically with clean periods and pollution episodes alternating frequently. Compared to summer, wintertime submicron aerosols show much enhanced organics and chloride, which on average account for $52 \%$ and $5 \%$, respectively, of the total NR-PM mass. All NR-PM 1 species show quite different diurnal behaviors between summer and winter. For example, the wintertime nitrate presents a gradual increase during daytime and correlates well with secondary organic aerosol (OA), indicating a dominant role of photochemical production over gasparticle partitioning. Positive matrix factorization was performed on ACSM OA mass spectra, and identified three primary OA (POA) factors, i.e., hydrocarbon-like OA (HOA), cooking OA (COA), and coal combustion OA (CCOA), and one secondary factor, i.e., oxygenated OA (OOA). The POA dominates OA during wintertime, contributing $69 \%$, with the other $31 \%$ being SOA. Further, all POA components show pronounced diurnal cycles with the highest concentrations occurring at nighttime. CCOA is the largest primary source during the heating season, on average accounting for $33 \%$ of $\mathrm{OA}$ and $17 \%$ of NR-PM 1 . CCOA also plays a significant role in chemically resolved particulate matter (PM) pollution as its mass contribution increases linearly as a function of NR$\mathrm{PM}_{1}$ mass loadings. The SOA, however, presents a reverse
\end{abstract}

trend, which might indicate the limited SOA formation during high PM pollution episodes in winter. The effects of meteorology on PM pollution and aerosol processing were also explored. In particular, the sulfate mass is largely enhanced during periods with high humidity because of fog processing of high concentration of precursor $\mathrm{SO}_{2}$. In addition, the increased traffic-related HOA emission at low temperature is also highlighted.

\section{Introduction}

Atmospheric fine particles exert highly uncertain radiative forcing impacts on climate change (Forster et al., 2007) and are detrimental to human health (Pope III et al., 2002). Aerosol particles also have series impacts on air quality and visibility reduction (Watson, 2002; Molina and Molina, 2004). In recent years, air pollution has become a major environmental concern in densely populated urban areas (Zhang et al., 2008b; Molina et al., 2010) due to large emissions of air pollutants from anthropogenic activities, e.g., traffic, industry, and power plants. However, the air pollution control remains a great challenge because of the very complex sources and evolution processes of aerosol particles. Knowledge of aerosol particle composition, sources and processes is of importance to reduce its harmful effects and improve air quality.

The particulate matter (PM) pollution in Beijing has improvement during the past decade (Chan and Yao, 2008); the visibility, however, is getting worse (Zhang et al., 2010). 
While the increasing moisture has played an important role, the consistently high concentration of fine particles $\left(\mathrm{PM}_{2.5}\right)$ might be another cause. Indeed, fine particles often exceed the new National Ambient Air Quality Standards of China $\left(75 \mu \mathrm{g} \mathrm{m}^{-3}\right.$ for $24 \mathrm{~h}$ average) during all seasons. Efforts to characterize sources and composition of fine particles thus have been extensively made in Beijing and regions in its vicinity. Most of the early studies rely on filter measurements (He et al., 2001; Yao et al., 2002; Duan et al., 2005; Sun et al., 2006; Zhao et al., 2013). Carbonaceous materials, watersoluble ions, including $\mathrm{SO}_{4}^{2-}, \mathrm{NO}_{3}^{-}$, and $\mathrm{NH}_{4}^{+}$, and mineral dust are found to be major constituents of fine particles in Beijing. However, the filter measurements with the sampling durations from hours to days are not sufficient enough to characterize the rapid evolution of atmospheric aerosols; for example, the aging of organic aerosol (OA) usually takes place in less than one day (Jimenez et al., 2009; DeCarlo et al., 2010). Further, the filter measurements might have significant loss of semi-volatile species, e.g., ammonium nitrate, due to the evaporative loss during the sampling (Dong et al., 2012).

In recent years, the real-time measurements of aerosol particle composition have been widely conducted in China using various online instruments, e.g., Ambient Ion Monitor (AIM, URG9000B) (Wu and Wang, 2007), Gas and Aerosol Collector - Ion Chromatography (IC) systems (GAC-IC) (Dong et al., 2012), analyzer for Monitoring for AeRosols and GAses (MARGA) (Du et al., 2011), and Aerosol Mass Spectrometers (AMS) (Huang et al., 2010; Sun et al., 2010), etc. Among them, AMS is a unique instrument which can provide both chemical composition and size distributions of non-refractory submicron aerosol species, including organics, sulfate, nitrate, ammonium, and chloride (Canagaratna et al., 2007). Due to the high sensitivity and the capability in aerosol composition detection, AMS measurements have gradually become the focus of recent studies (Takegawa et al., 2009; Huang et al., 2010; Sun et al., 2010; Liu et al., 2012). Despite this, most instruments above need to be maintained routinely in order to obtain high-quality data. The long-term measurements, therefore, still remain a challenge. Aerodyne Aerosol Chemical Speciation Monitor (ACSM) was recently developed based on AMS (Ng et al., 2011b). The ACSM is specially designed for routine and long-term measurements of aerosol particle composition and mass concentration, yet not size information. The first deployment of ACSM in Beijing, China, shows good performance and provides rich chemical information on aerosol particles (Sun et al., 2012). With all these efforts in aerosol measurements, a number of conclusions and new findings have been obtained which have significantly improved our understanding of aerosol sources and processes in China. In particular, organics is found to be a major component of fine particles, accounting for more than one-third of total mass. The primary organic aerosol (POA) from traffic, cooking, and coal combustion etc., and secondary OA (SOA) are distinguished and quantified using various receptor models, e.g., chemical mass balance (CMB, e.g., Zheng et al., 2005) and positive matrix factorization (PMF; e.g., Song et al., 2006). SOA dominates OA most of the time in summer, and is one of the major factors leading to high PM pollution. In addition, the relationship between chemically resolved PM pollution and meteorology has also been explored to some extent.

Most previous AMS measurements in Beijing were conducted in summer with a major focus on photochemical processing. However, the aerosol composition, sources and processes may vary very differently between summer and winter because of different meteorology and source emissions. For example, a recent study in the winter of 2010 by a HighResolution Time-of-Flight AMS (HR-ToF-AMS) found that SOA only accounts for $24 \%$ of the total OA, with the rest being POA (Liu et al., 2012). The oxidation degree of OA is much reduced in winter, and the size distributions shift from a large accumulation mode peaking at $\sim 600 \mathrm{~nm}$ to $\sim 450 \mathrm{~nm}$ (Huang et al., 2010; Sun et al., 2010; Liu et al., 2012). In order to better characterize aerosol composition and sources during wintertime, an ACSM was deployed from 21 November 2011 to 20 January 2012 at the same site as that in summer (Sun et al., 2012). Here we have a detailed characterization of submicron aerosol species including mass concentrations, chemical composition, diurnal variations, and day-ofweek patterns during wintertime, and compare with those observed in summer. Then, we perform source apportionment analysis using PMF to investigate the source categories and evolution processes of OA. Finally we provide some insights into the chemically resolved PM pollution and its association with meteorology during wintertime.

\section{Experimental}

\subsection{Aerosol and gas measurements}

The non-refractory submicron $\left(\mathrm{NR}-\mathrm{PM}_{1}\right)$ aerosol species including organics, sulfate, nitrate, ammonium, and chloride were measured in situ at the same location as Sun et al. (2012), i.e., Institute of Atmospheric Physics (IAP), Chinese Academy of Sciences, located between the 3rd and 4th ring road in Beijing, from 21 November 2011 to 20 January 2012 with an ACSM. The aerosol sampling setup and the ACSM operations in this study were also the same as those in Sun et al. (2012). In addition to ACSM deployment, the $\mathrm{PM}_{2.5}$ mass was simultaneously measured by a heated Tapered Element Oscillating Microbalance (TEOM series1400a, Thermo Scientific), and collocated gaseous species including $\mathrm{CO}, \mathrm{SO}_{2}, \mathrm{NO} / \mathrm{NO}_{\mathrm{y}}$, and $\mathrm{O}_{3}$ were measured by various gas analyzers (Thermo Scientific). The meteorology data (wind speed, wind direction, relative humidity $(\mathrm{RH})$, temperature, pressure, precipitation and solar radiation) during this study were obtained from the IAP tower that 
is approximately $30 \mathrm{~m}$ away and the ground meteorology station that is $\sim 20 \mathrm{~m}$ away.

\subsection{ACSM data analysis}

The mass concentrations and mass spectra were processed using ACSM standard data analysis software (v 1.5.1.1). The detailed procedures for the data analysis have been described in Ng et al. (2011b) and Sun et al. (2012). In particular, a collection efficiency (CE) was introduced to compensate for the particle loss, mostly due to particle bounce at the vaporizer (Matthew et al., 2008). Although $\mathrm{CE}=0.5$ is appropriate for most field studies (Canagaratna et al., 2007), it also varies depending on the acidity of aerosol particles, aerosol composition, and particle phase water (Matthew et al., 2008). Given that aerosol particles were dried before sampling into the ACSM system and that they are overall neutralized in Beijing (Huang et al., 2010; Sun et al., 2010), the particle phase water and acidity are expected to play minor roles in affecting $\mathrm{CE}$ values. Therefore, we use a composition-dependent CE recommended by Middlebrook et al. (2012), i.e., $\mathrm{CE}=$ $\max (0.45,0.0833+0.9167 \times$ ANMF $)$ in this study. ANMF is the mass fraction of ammonium nitrate in NR-PM $\mathrm{PM}_{1}$.

The PMF with PMF2.exe algorithm (Paatero and Tapper, 1994) in robust mode was performed on ACSM mass spectra to deconvolve OA into distinct factors. Similar to our previous study (Sun et al., 2012), we limited our PMF analysis to $m / z 120$ due to large interferences of internal standard of naphthalene at $m / z$ 's $127-129$. The PMF results were further evaluated with an Igor-Pro-based PMF Evaluation Tool (PET, v2.04) (Ulbrich et al., 2009), and the number of PMF factors were determined following the procedures detailed in Zhang et al. (2011). In summer, PMF analysis only resolved two OA factors: a hydrocarbon-like OA (HOA) and an oxygenated OA (OOA). In winter, PMF analysis showed better deconvolution of OA factors, and it was able to identify four components including three primary OA, i.e., HOA, cooking OA (COA), and coal combustion OA (CCOA), and one secondary OA, i.e., OOA.

\section{Results and discussion}

\subsection{Mass concentration}

Figure 1 shows the time series of NR-PM 1 and $\mathrm{PM}_{2.5}$ mass, submicron aerosol species, and meteorology for the entire study. Similar to the results observed in summer (Sun et al., 2012), the NR-PM 1 mass measured by the ACSM tracks well the $\mathrm{PM}_{2.5}$ measured by the TEOM $\left(r^{2}=0.77\right.$, Fig. S1). The correlation between NR-PM $\mathrm{P}_{1}$ and $\mathrm{PM}_{2.5}$ yields a regression slope of 0.74 , mainly because ACSM only measures $\mathrm{PM}_{1}$ and also does not detect refractory materials, e.g., mineral dust and black carbon at vaporizer temperature of $\sim 600^{\circ} \mathrm{C}$. Note that the ratio of NR-PM $/ \mathrm{PM}_{2.5}$ is often close to 1 as shown in Fig. S1. One of the reasons is the evaporative loss of semi-volatile materials (SVM, e.g., ammonium nitrate and semi-volatile organics) for the TEOM measurements that were operated at $50^{\circ} \mathrm{C}$ (Eatough et al., 2003). For example, a significant loss $(\sim 50 \%)$ of SVM for the heated TEOM in comparison to the one with the SVM collected was reported during the SOAR-1 study (Docherty et al., 2011). Indeed, the correlation between NR-PM 1 and $\mathrm{PM}_{2.5}$ appears to be dependent on the mass fraction of sulfate and OOA that are less-volatile components in the aerosols. A higher fraction of less-volatile sulfate and OOA corresponds to a lower ratio of NR-PM $1 / \mathrm{PM}_{2.5}$. The higher ratio of NR-PM $/ \mathrm{PM}_{2.5}$ in winter than summer (0.64) is also likely due to the evaporative loss of more semi-volatile materials in winter.

The daily average concentration of the total NR-PM $\mathrm{PM}_{1}$ mass ranges from 6.6 to $192 \mu \mathrm{g} \mathrm{m}^{-3}$ with an average value of 66.8 $( \pm 55) \mu \mathrm{g} \mathrm{m}^{-3}$ for the entire study, which is $\sim 30 \%$ higher than that observed in the summer of 2011 (Sun et al., 2012). The daily average mass concentration often exceeds the $24 \mathrm{~h}$ NAAQS of the US EPA of $\left(35 \mathrm{\mu g} \mathrm{m}^{-3}\right)$ and the second grade of NAAQS $\left(75 \mu \mathrm{g} \mathrm{m}^{-3}\right)$ released in 2012 by the Ministry of Environmental Protection (MEP) of the People's Republic of China (http://kjs.mep.gov.cn/hjbhbz/bzwb/dqhjbh/ dqhjzlbz/201203/t20120302_224165.htm). When converting the measured NR-PM 1 to $\mathrm{PM}_{2.5}$ using a factor of 0.74 , we calculate that $\sim 80 \%$ and $54 \%$ of days during wintertime exceed the NAAQS of US EPA and China MEP, respectively. This suggests that the fine particle pollution is still a major environmental concern in Beijing although it has been improved during the past decade (Chan and Yao, 2008). Considering the complexity of sources, properties, and processes of fine particles, the road to achieve the $\mathrm{PM}_{2.5}$ standard remains a challenge (Yuan et al., 2012).

The mass concentration of total NR-PM 1 varies very dramatically across the entire study. In particular, the clean events with NR-PM $1<\sim 15 \mu \mathrm{g} \mathrm{m}^{-3}(\sim 24 \%$ of the time $)$ and the highly polluted episodes $\left(>100 \mu \mathrm{g} \mathrm{m}^{-3}, \sim 25 \%\right.$ of the time) occur alternatively. The clean periods are often short, typically less than 2 days. In contrast, the high PM pollution events persist a longer time and sometimes over one week. The switch of clean and polluted days is strongly associated with the synoptic meteorology in Beijing. As shown in Fig. 1, the clean periods are associated with high wind speed and dominant westerly and northwesterly winds. Comparatively, the high PM pollution episodes are generally related to southerly and easterly winds with low wind speed $\left(<\sim 1.5 \mathrm{~m} \mathrm{~s}^{-1}\right)$. Such meteorology patterns influencing aerosol species in Beijing have been observed many times in previous studies (Huang et al., 2010; Sun et al., 2010, 2012; Zhang et al., 2012b). Also note that wet scavenging plays a minor role in changing aerosol mass loadings given the very low precipitation during the study. 


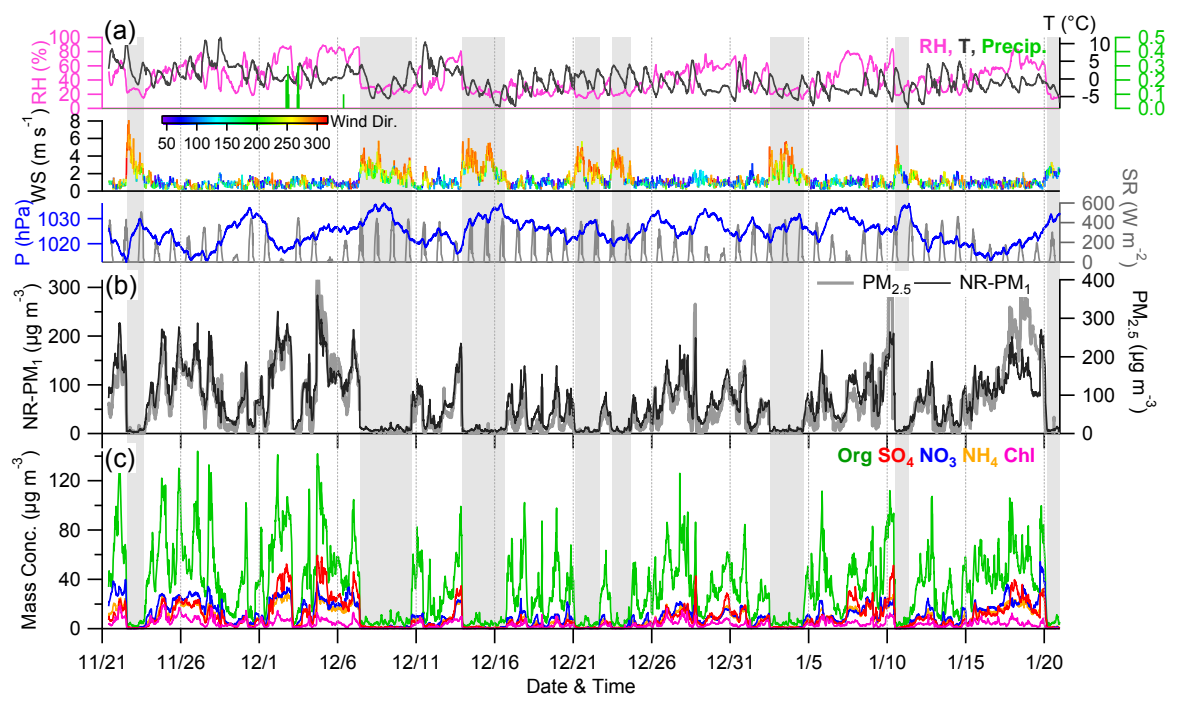

Fig. 1. Time series of (a) meteorological variables (relative humidity, temperature, precipitation, wind speed, wind direction, pressure, and solar radiation), (b) total NR-PM 1 and $\mathrm{PM}_{2.5}$, and (c) $\mathrm{NR}-\mathrm{PM}_{1}$ species $\left(\mathrm{Org}, \mathrm{SO}_{4}, \mathrm{NO}_{3}, \mathrm{NH}_{4}\right.$, and Chl) for the entire study. The clean periods with low aerosol mass loadings are marked as gray shaded areas.

\subsection{Submicron aerosol composition and diurnal variations}

All submicron aerosol species show very dynamic variations day by day, with the minimum and maximum of daily average concentrations being larger than 20 times, and even close to an order of 2 (e.g., chloride). In particular, organics shows an obvious sawtooth structure with the variation of mass concentration up to $100 \mu \mathrm{g} \mathrm{m}^{-3}$ in one day. PMF analysis of OA in Sect. 3.3 suggests that such structure is mainly caused by the variations of primary OA, e.g., COA and CCOA. Overall, the NR-PM $\mathrm{PM}_{1}$ in winter is dominated by organics with an average contribution of $52 \%$ (Fig. 2a). Compared to $\sim 40 \%$ observed in summer (Huang et al., 2010; Sun et al., 2010, 2012), organics is more important in PM pollution in winter. Indeed, the average mass concentration of organics is 34.4 $( \pm 27.9) \mu \mathrm{g} \mathrm{m}^{-3}$ in winter, which is almost twice higher than that in the summer of 2011 (Sun et al., 2012). The contribution of organics to NR-PM 1 is even higher during the clean periods $(63 \%)$, which is consistent with our previous observations in Beijing that the air masses from the upwind areas of Beijing are characterized by high mass fraction of organics (Sun et al., 2012). As a comparison, the inorganic species sulfate and nitrate show relatively lower contribution to the total NR-PM ${ }_{1}$ mass in winter (14\% and $16 \%$, respectively) than summer although the mass concentrations between the two seasons are rather similar (Table 1). Chloride accounts for a small fraction of NR-PM 1 in winter $(5 \%)$ yet has the largest seasonal difference among NR-PM ${ }_{1}$ species. The mass concentration in winter is $\sim 7$ times higher than that in summer, likely due to the intensified emissions from coal combustion during the heating season.

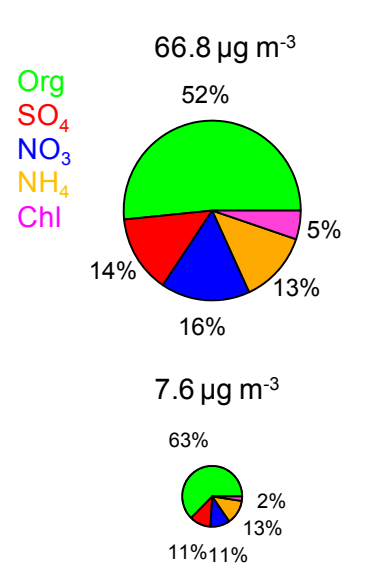

(a)

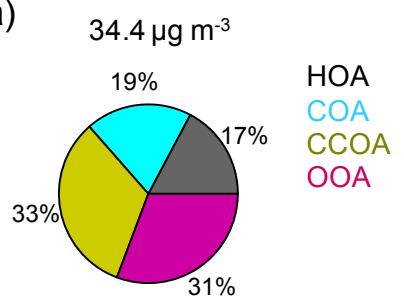

(b)

$$
4.8 \mu \mathrm{g} \mathrm{m}^{-3}
$$

Fig. 2. Average chemical composition of NR-PM 1 and OA for the (a) entire study and for (b) clean periods marked in Fig. 1.

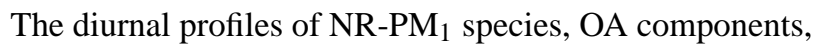
and meteorological variables for the entire study and clean periods are presented in Fig. 3. Organics shows a pronounced diurnal cycle with the highest concentration occurring at nighttime $\left(\sim 54 \mu \mathrm{g} \mathrm{m}^{-3}\right)$ and the lowest value during daytime $\left(\sim 24 \mu \mathrm{g} \mathrm{m}^{-3}\right)$. Our lidar measurements show that the diurnal variation of planetary boundary layer (PBL) height during the study period is relatively flat, indicating that PBL might play a minor role in driving the time-of-day variation during wintertime. Therefore, we infer that the high concentration of organics at nighttime is mainly associated with the primary organics from local emissions, in agreement with the diurnal profiles of primary OA components, e.g., HOA, 
Table 1. Summary of mass concentrations $\left(\mu \mathrm{g} \mathrm{m}^{-3}\right)$ of NR-PM $\mathrm{P}_{1}$ species and OA components.

\begin{tabular}{|c|c|c|c|c|c|c|c|}
\hline & \multicolumn{5}{|c|}{ Winter, 2011} & \multirow{2}{*}{$\begin{array}{r}\text { Summer, } 2011^{\mathrm{b}} \\
\text { Jul-Aug }\end{array}$} & \multirow[t]{2}{*}{$\mathrm{W} / \mathrm{S}^{\mathrm{c}}$} \\
\hline & Entire & Clean $^{a}$ & Day & Night & Night/Day & & \\
\hline Org & 34.4 & 4.8 & 25.1 & 40 & 1.59 & 20.0 & 1.72 \\
\hline $\mathrm{HOA}$ & 5.8 & 0.7 & 3.6 & 7.1 & 1.96 & 7.1 & $3.34^{\mathrm{d}}$ \\
\hline $\mathrm{COA}$ & 6.6 & 1.7 & 3.7 & 8.4 & 2.30 & & \\
\hline $\mathrm{CCOA}$ & 11.3 & 0.5 & 7.2 & 13.7 & 1.90 & & \\
\hline OOA & 10.7 & 1.9 & 10.6 & 10.7 & 1.01 & 12.7 & 0.85 \\
\hline $\mathrm{SO}_{4}$ & 9.3 & 0.9 & 7.7 & 10.2 & 1.33 & 9.0 & 1.03 \\
\hline $\mathrm{NO}_{3}$ & 10.9 & 0.8 & 10.1 & 11.2 & 1.10 & 12.4 & 0.88 \\
\hline $\mathrm{NH}_{4}$ & 8.6 & 1.0 & 7.5 & 9.3 & 1.24 & 8.0 & 1.08 \\
\hline Chl & 3.5 & 0.2 & 2.5 & 4.1 & 1.64 & 0.5 & 6.82 \\
\hline Total $^{\mathrm{e}}$ & 66.8 & 7.6 & 74.8 & 52.9 & 1.42 & 49.9 & 1.34 \\
\hline
\end{tabular}

${ }^{\text {a }}$ Clean periods as marked in Fig. 1.

${ }^{\mathrm{b}}$ Sun et al. (2012).

c Winter/Summer.

$\mathrm{d}$ The ratio is calculated as $(\mathrm{HOA}+\mathrm{COA}+\mathrm{CCOA})_{\text {winter }} / \mathrm{HOA}_{\text {summer }}$.

${ }^{\mathrm{e}}$ Total $=\mathrm{Org}+\mathrm{SO}_{4}+\mathrm{NO}_{3}+\mathrm{NH}_{4}+\mathrm{Chl}$

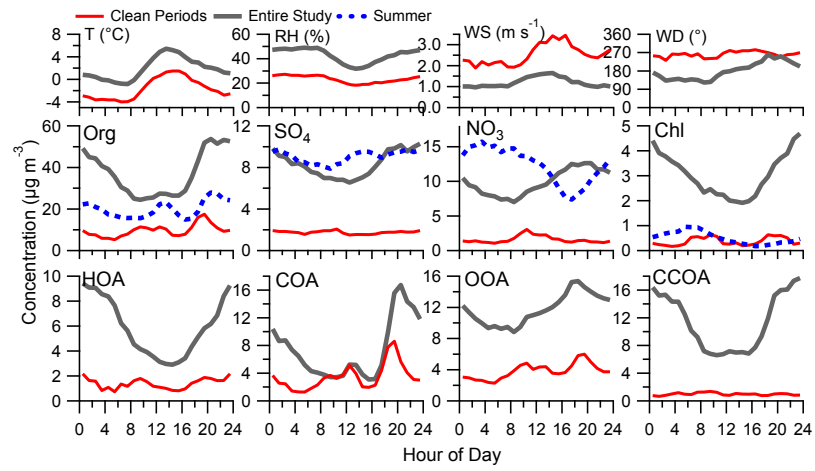

Fig. 3. Diurnal profiles of NR-PM 1 species, OA components, and meteorological variables for the entire study and clean periods

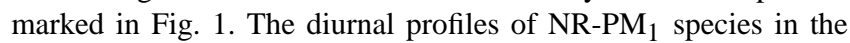
summer of 2011 (Sun et al., 2012) are also shown for a comparison. Note that the diurnal profiles of aerosol species during the clean periods were all enhanced by a factor of 2 for clarity.

CCOA, and COA (Sect. 3.3). In addition, the relatively lower wind speed and higher humidity at nighttime might also have played a role. The organics contributes the major fraction of NR-PM 1 throughout the day, ranging from $48-60 \%$, and the contribution increases to $53-75 \%$ during the clean periods. Note that a small peak for organics was observed at noon time due to the influences of cooking emissions, but this noon peak is much smaller in comparison to that observed in summer (Sun et al., 2012). The diurnal cycle of organics during the clean periods shows some differences, which is characterized by two peaks corresponding to meal times. This diurnal pattern more closely resembles that observed in summer (Huang et al., 2010; Sun et al., 2010, 2012), implying that local cooking-related emissions play an important role in organic chemistry during the clean periods. Interestingly, a third peak between 08:00 and 09:00 LT was also observed, which might be from the emissions of cooking breakfast.

Sulfate shows quite different diurnal behaviors between summer and winter. The sulfate in summer presents an enhanced noon peak associated with the photochemical processing (Sun et al., 2012). However, such a noon peak is not observed in winter. This might suggest that the gas-phase photochemical production of sulfate particles is less significant in winter with low temperature and solar radiation. Instead, we found that the sulfur oxidation ratio shows a strong and positive RH dependency (Sun et al., 2013), indicating that aqueous processing might have played a more important role in the formation of sulfate. This is further supported by the synchronous increase of sulfate and RH from 12:00 to the late afternoon despite the rising boundary layer. In comparison, sulfate shows a very flat pattern during the clean periods, demonstrating the regional characteristics of sulfate. Sulfate, overall, accounts for a relatively consistent contribution (11$15 \%)$ to the total NR-PM 1 throughout the day.

Nitrate shows the largest different diurnal cycle between summer and winter. As the gas-phase photochemical production and temperature-dependent gas-particle partitioning are both important for nitrate formation in summer, the wintertime nitrate appears to be mainly driven by the photochemical production, which shows a linear increase from $\sim 7 \mu \mathrm{g} \mathrm{m}^{-3}$ at 08:00 to $12.5 \mu \mathrm{g} \mathrm{m}^{-3}$ at 17:00 with a growth rate of $\sim 0.6 \mu \mathrm{g} \mathrm{m}^{-3} \mathrm{~h}^{-1}$. Further, nitrate shows a very similar diurnal pattern and tight correlation with OOA - a surrogate of SOA $\left(r^{2}=0.80\right)$ - confirming the importance of photochemical processing in controlling the diurnal variations of nitrate during wintertime. In addition, the ambient temperature across the entire study is generally low $\left(<12{ }^{\circ} \mathrm{C}\right)$, and the evaporative loss of ammonium nitrate particles due 
to gas-particle partitioning would not be significant. The results together suggest that the dominant formation mechanisms of nitrate in summer and winter are very different. The nitrate shows a sharp morning peak during the clean periods, which is very similar to that of NO, yet with a time lag of $\sim 2 \mathrm{~h}$. Such a diurnal pattern was also observed in Mexico City during the MCMA-2003 campaign, which is attributed to photochemical production of nitric acid from $\mathrm{NO}_{2}$ and $\mathrm{OH}$ (Salcedo et al., 2006).

Chloride also shows significantly different diurnal cycles between summer and winter. In summer when the emissions of coal combustion are small, chloride shows a gradual decrease from early morning to late afternoon due to the evaporative loss and dilution effects associated with elevated boundary layer. Comparatively, the diurnal cycle of chloride in winter is quite different, with the highest concentration occurring at midnight and the lowest value at noon. Interestingly, while $\mathrm{NH}_{4} \mathrm{Cl}$ and $\mathrm{NH}_{4} \mathrm{NO}_{3}$ share similar volatile properties and often correlate well with each other (Ulbrich et al., 2009; Sun et al., 2011), the different diurnal cycles of chloride and nitrate in this study indicate their different sources and mechanisms. While photochemical production is the major process of nitrate formation during wintertime, the direct coal combustion emissions are the major source of chloride. Consistently, the diurnal cycles of chloride and coal combustion OA are very similar, further supporting our conclusion. The chloride during the clean periods is characterized by two pronounced peaks occurring in the early morning and evening, which is likely due to the contribution from local sources.

An even simpler comparison of diurnal variations is daynight differences. In this study, the daytime is defined as the period between sunrise and sunset, which is approximately $\sim 06: 45-17: 30$, and the rest of day is classified as nighttime. As shown in Table 1, the three primary OA components, i.e., HOA, COA, and CCOA, and chloride show the largest daynight differences, with the nighttime concentrations being twice higher than daytime concentrations. The secondary inorganic species $\left(\mathrm{SO}_{4}, \mathrm{NO}_{3}\right.$, and $\left.\mathrm{NH}_{4}\right)$ and $\mathrm{OOA}$, however, did not show very clear day-night differences, yet had $\sim 10$ $30 \%$ higher concentration at nighttime. The day-night differences appear to be strongly dependent on relative humidity (Fig. 4). As the day-night RH differences are larger than $10 \%$, most aerosol species including the secondary inorganic species often show more than twice the differences in mass concentrations, highlighting the role of RH in PM pollution in winter. As mentioned in Sect. 3.2, the PBL plays a less significant role in winter than summer; thus, high concentrations of aerosol species at high RH are likely due to (1) accumulation of pollutants associated with stagnant conditions, (2) production via aqueous processing, and (3) gasparticle partitioning due to water uptake (Hennigan et al., 2008) and low temperature (Ranjan et al., 2012). It should be noted that even when the day-night RH differences are small, POA components also show much higher concentra-

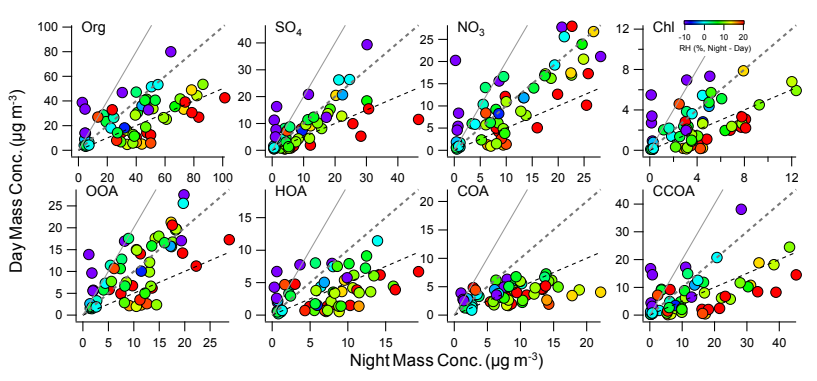

Fig. 4. Day-night comparisons of NR-PM 1 aerosol species and OA components. The data points are color-coded with night-day $\mathrm{RH}$ differences. The three lines in the plot refer to $2: 1,1: 1$, and $1: 2$ lines, respectively.

tions at nighttime than daytime, suggesting the enhanced primary emissions from coal combustion, traffic and cooking activities at nighttime.

\subsection{OA composition and sources}

PMF analysis of wintertime OA spectra resolved four OA components, i.e., HOA, COA, CCOA, and OOA, of which the mass spectra and time series are presented in Fig. 5, and their diurnal profiles are shown in Fig. 3.

\subsubsection{Hydrocarbon-like OA (HOA)}

The mass spectral pattern of HOA is characterized by hydrocarbon ion series of $m / z 27,41$, and 55, typical of cycloalkanes, and $m / z 29,43$, and 57, typical of alkanes (McLafferty and Turecek, 1993). Note that the peak intensities of $\mathrm{C}_{n} \mathrm{H}_{2 n-1}^{+}$is about twice lower than $\mathrm{C}_{n} \mathrm{H}_{2 n+1}^{+}$. This spectral pattern is quite different from the HOA spectrum resolved previously by an HR-ToF-AMS in summer (Huang et al., 2010), and the standard HOA spectrum observed worldwide (Ng et al., 2011a), yet shows much similarity to that identified in winter in Beijing (Liu et al., 2012; Zhang, 2011), and the spectrum of pure diesel fuel aerosols (Canagaratna et al., 2004) and unreacted diesel exhaust (Kroll et al., 2012). The results suggest that HOA in winter, which is emitted at low ambient temperature and low atmospheric oxidants, might be very fresh, while HOA in summer might have been oxidized to some extent already. The mass spectral difference of HOA between summer and winter is also likely due to the significant temperature differences leading to different emissions of hydrocarbons. For example, Lough et al. (2005) found an increase of lighter hydrocarbons in winter in comparison to summer based on on-road vehicle emissions measurements in two tunnels.

The time series of HOA varies dramatically day by day and correlates well with $\mathrm{CO}\left(r^{2}=0.68\right)$, consistent with a number of previous studies' findings that HOA is mainly associated with combustion-related emissions, e.g., diesel exhaust (Zhang et al., 2005; Canagaratna et al., 2010; Massoli 

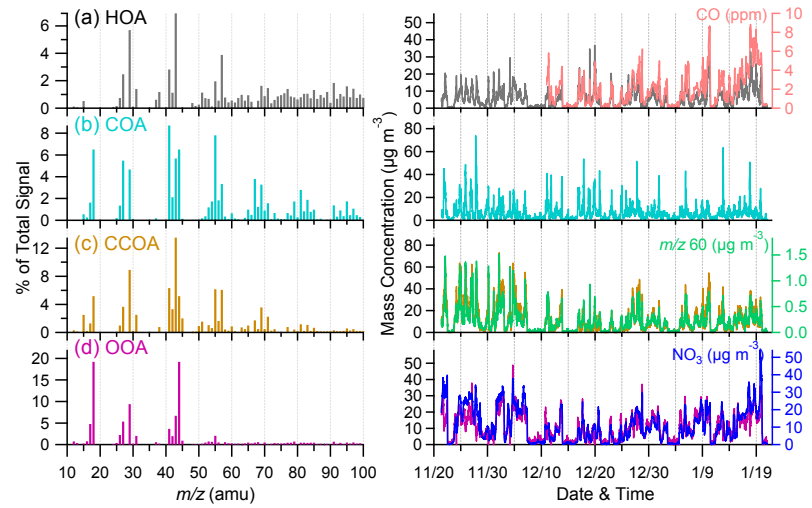

Fig. 5. Mass spectra and time series of mass concentrations of four OA components (HOA, COA, CCOA, and OOA).

et al., 2012). However, HOA does not present a morning rush hour peak as do previous studies at other urban sites (Aiken et al., 2009; Sun et al., 2011); in contrast, HOA presents a pronounced diurnal cycle with the highest concentration at night $\left(9.4 \mu \mathrm{g} \mathrm{m}^{-3}\right)$ and the lowest value during late afternoon $\left(2.9 \mu \mathrm{g} \mathrm{m}^{-3}\right)$. This diurnal cycle is remarkably similar to that of the number of heavy duty vehicles (HDV) and heavy duty diesel trucks (HDDT) in Beijing (Han et al., 2009) that are not allowed inside the city between 06:00 and 22:00. Therefore, the diurnal cycle of HOA is more likely driven by the traffic emissions from HDV and HDDT. HOA, during clean periods, shows two visible peaks during morning and evening rush hours due to local traffic emissions and/or those transported from outside city. Overall, the average mass concentration of HOA for the entire study is $5.8 \mu \mathrm{g} \mathrm{m}^{-3}$ (17\% of $\mathrm{OA}$ ), with the highest contribution to OA at nighttime (22\%) and the lowest during daytime $(11 \%)$. The contribution of HOA to OA is close to $18 \%$ as observed in the summer of 2008 (Huang et al., 2010), yet slightly lower than $21 \%$ in the winter of 2010 (Liu, 2012).

\subsubsection{Cooking OA (COA)}

The recent PMF-AMS has identified a cooking-related OA (COA) component with distinct spectral profile and diurnal cycle at various urban sites, e.g., NYC, Beijing, Fresno, Barcelona, and Manchester (Allan et al., 2010; Huang et al., 2010; Sun et al., 2011; Ge et al., 2012; Mohr et al., 2012). The COA is generally characterized by prominent peaks of $m / z 55$ (mainly $\mathrm{C}_{3} \mathrm{H}_{3} \mathrm{O}^{+}, \mathrm{C}_{4} \mathrm{H}_{7}^{+}$) and 57 (mainly $\mathrm{C}_{3} \mathrm{H}_{5} \mathrm{O}^{+}$, $\mathrm{C}_{4} \mathrm{H}_{9}^{+}$) with the spectral pattern resembling that of OA from fresh cooking emissions (He et al., 2010; Mohr et al., 2012). While the ratio of $m / z 55 / 57(=2.3)$ is close to the values previously observed in Beijing (Huang et al., 2010; Liu et al., 2012), the COA spectrum in this study shows a relatively higher fraction of $m / z 44$, yet resembles more closely that observed in NYC (Sun et al., 2011). The diurnal cycle of $\mathrm{COA}$ is characterized by two pronounced peaks correspond- ing to lunch and dinner times. Similar diurnal behavior of COA was also observed at the PKU site in Beijing in 2008 (Huang et al., 2010). Note that at the same site of IAP, the COA shows larger differences between noon and evening peak in winter than summer. Given that cooking activities are expected to be similar in the two seasons, the enhanced COA concentration at night during wintertime might be mainly due to the low temperature, which facilitates gas-particle partitioning of semi-volatile OA species, and hence enhances the $\mathrm{COA}$ emissions. Interestingly, the COA during the clean periods shows a third peak in the morning, likely from the contribution of breakfast.

COA has been found to be an important source contribution of OA $(\sim 16-30 \%)$ at various urban sites, and often COA is comparable and even higher than the traffic-related HOA. In this study, COA on average accounts for $19 \%$ of $\mathrm{OA}$, with the highest contribution of $32 \%$ during dinner time and the lowest of $11 \%$ during late afternoon. The contribution of COA to OA is close to that reported at the PKU site in Beijing in the summer of 2008 (Huang et al., 2010) and falls within the range observed at other urban sites. It should be noted that the average contribution of COA to OA increases to $36 \%$ during the clean periods, and even goes up to $\sim 50 \%$ at dinner time. These results suggest that COA is an important local source of OA in Beijing, particularly during clean periods.

\subsubsection{Coal combustion OA (CCOA)}

The wintertime PMF analysis resolved an OA factor showing overall a similar spectral pattern to that of standard biomass burning OA (BBOA) (Ng et al., 2011a), yet with a much lower fraction of $m / z 60$ and 73 - AMS marker $m / z$ 's for BB (Alfarra et al., 2007; Mohr et al., 2009). In contrast, the mass spectrum shows more similarity to that of OA from pulverized coal combustion under certain oxygen / carbon ratios (Wang et al., 2013). Further, this OA factor was only resolved during the heating season based on PMF analysis of ACSM OA spectra from one-year measurement (Sun, 2012). These results suggest a different OA factor in this study from the common BBOA and/or wood combustion OA, which is very likely an $\mathrm{OA}$ factor representing coal combustion sources with significantly enhanced emissions during wintertime. Coal combustion in China has been found to emit a large quantity of carbonaceous aerosols, contributing 70\% of total emitted $\mathrm{PM}_{2.5}$ (Zhang et al., 2012a). While the polycyclic aromatic hydrocarbons (PAHs) and n-alkanes are the major components of OA ( $38 \%$ and $20 \%$, respectively) from the coal combustion, levoglucosan only accounts for a minor fraction, up to $1.1 \%$ of OC (Zhang et al., 2008a). This is overall consistent with the low fraction of $m / z 60(f 60)$ and the hydrocarbon ion series (e.g., $\mathrm{C}_{n} \mathrm{H}_{2 n-1}^{+}$and $\mathrm{C}_{n} \mathrm{H}_{2 n+1}^{+}$) observed in this factor. Similar low $f 60$ was also observed in the mass spectra of OA from pulverized coal combustion (Wang et al., 2013). In addition, the diurnal profile of $f 60$ 
during wintertime (Fig. S2) shows a pronounced diurnal cycle with all values $(0.52-0.71 \%)$ much higher than $\sim 0.3 \%$ in the absence of biomass burning (Aiken et al., 2009), confirming the significant impact of combustion source emissions on OA. In contrast, coal combustion shows minor impacts on $\mathrm{OA}$ in summer, as suggested by the values of $f 60$ close to $\sim 0.3 \%$, although slightly higher values were observed at night. Considering the above, we conclude that this factor is primarily a coal-combustion-related OA factor (CCOA). Not surprisingly, CCOA correlates tightly with chloride $\left(r^{2}=0.81\right)$ since the coal combustion is also an important source of chloride (Zhang et al., 2012a).

CCOA shows a pronounced diurnal cycle similar to chloride. The CCOA concentration reaches a maximum of

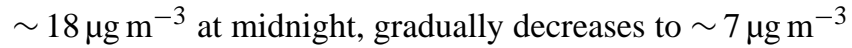
at 08:00-09:00, and remains at a constant level till 15:0016:00. This diurnal cycle is consistent with the source emissions from heating activities which are intensified at nighttime. Indeed, we often can smell coal combustion at nighttime and in the early morning. Similar diurnal cycles of wood-burning OA with enhanced emissions at night during wintertime were also observed at other urban sites, e.g., Fresno, CA (Ge et al., 2012), and Paris (Crippa et al., 2013). Likely, the high concentration of CCOA at night is also partially due to the partitioning of semi-volatile water-soluble organic species from gas phase to particle phase, which is facilitated by the higher humidity (Hennigan et al., 2009). Indeed, CCOA is the only OA component with the contribution to OA increasing as a function of relative humidity (Sun et al., 2013). The CCOA shows a flat diurnal pattern with very low mass concentrations during clean periods, and the average contribution of CCOA to OA drops to $10 \%$. The high wind speeds and the clean air brought by northwesterly winds are likely the major reasons for the low CCOA during the clean periods.

CCOA is the most important primary source during wintertime, on average accounting for $33 \%$ of $\mathrm{OA}$ and $17 \%$

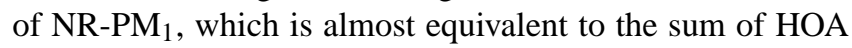
and COA. CCOA also contributes a considerable fraction of OA and NR-PM ${ }_{1}$ throughout the day, ranging from 26-37\% and $12-22 \%$, respectively, indicating a sustained impact of coal combustion on PM pollution throughout the whole day. Therefore, measures to reduce coal combustion emissions would be effective to improve air quality and visibility in Beijing during wintertime. With this, we expect an improvement of PM pollution in the next few years as the progression of boiler renovation from coal combustion to natural gas.

\subsubsection{Oxygenated OA (OOA)}

Similar to previously reported OOA (Zhang et al., 2005; Ng et al., 2010; $\mathrm{Ng}$ et al., 2011a), the mass spectrum of OOA in this study is characterized by the prominent peak of $\mathrm{m} / \mathrm{z}$ $44\left(\mathrm{CO}_{2}^{+}\right)(19.4 \%$ of the total OOA signal). Although OOA shows more a similar spectral pattern to that of highly ox- idized LV-OOA than freshly aged SV-OOA, it doesn't necessarily indicate that OOA during wintertime is highly aged. Firstly, the $m / z 44$ in OOA might be overestimated due to the exclusion of $m / z$ 's larger than 120 and some $m / z$ 's (e.g., $m / z 14,39$, etc.) that are not included in PMF analysis ( $\mathrm{Ng}$ et al., 2011b). Secondly, OOA shows better correlation with $\mathrm{NO}_{3}\left(r^{2}=0.80\right)$ than $\mathrm{SO}_{4}\left(r^{2}=0.63\right)$, which is similar to the results from a recent HR-ToF-AMS study conducted in Fresno, CA (Ge et al., 2012). Previous studies have shown that $\mathrm{NO}_{3}$ often correlates well with SV-OOA because of their similar volatilities. Therefore results above suggest that OOA in this study might be less photochemically processed than expected.

The time series of OOA varies very dramatically from the three POA components. As POA shows dynamic variations from day to night due to influences from local emissions, OOA often remains at a high concentration across several days until a change of air mass occurs. The OOA shows a pronounced diurnal cycle with the concentration being increased from $\sim 9 \mu \mathrm{g} \mathrm{m}^{-3}$ at 8:00 to $\sim 15 \mu \mathrm{g} \mathrm{m}^{-3}$ at 18:00. The contribution of OOA to the total OA also varies similarly across the day, with the highest contribution of $\sim 50 \%$ occurring at late afternoon. The gradual increase of OOA during daytime is indicative of photochemical production of SOA. Comparatively, OOA shows relatively stable contributions to OA during clean periods. On average, OOA accounts for $31 \%$ of total OA in wintertime, with the other $\sim 70 \%$ being primary OA. Even though OOA accounts for a higher fraction of OA during clean periods ( $40 \%$ ), it is still much lower than $\sim 60 \%$ as observed in summer (Huang et al., 2010; Sun et al., 2010, 2012), which illustrates the dominance of POA in winter and OOA in summer.

The OOA correlates well with secondary inorganic species $\mathrm{NO}_{3}$ and $\mathrm{SO}_{4}\left(r^{2}=0.79\right)$, consistent with the conclusions from previous AMS studies in Beijing (Huang et al., 2010; Sun et al., 2010, 2012). However, the correlations between OOA and secondary inorganic species during wintertime appear to be strongly dependent on relative humidity, in particular for sulfate. As the correlation coefficients remain significant from $r^{2}=0.80$ at $\mathrm{RH}<20 \%$ to $r^{2}=\sim 0.60$ at $\mathrm{RH}>50 \%$, the ratio of OOA $/ \mathrm{SO}_{4}$ decreases from 2.9 to $<1$, indicating the different roles of photochemical and aqueous processing in the formation of $\mathrm{OOA}$ and $\mathrm{SO}_{4}$ during wintertime. Particularly, we observed a more significant enhancement of $\mathrm{SO}_{4}$ than $\mathrm{OOA}$ and $\mathrm{NO}_{3}$ during the foggy events (e.g., 4-7 December), which might suggest that fog processing plays a more important role in sulfate production. More details can be found in Sect. 3.6.

\subsection{Day-of-week variations}

The day-of-week patterns for non-refractory aerosol species and OA components are shown in Fig. 6. No pronounced day-of-week patterns for both primary and secondary species, yet higher concentration on Monday and Tuesday 
and lower concentration on Wednesday, were observed. The average weekday and weekend differences are less than $7 \%$ for all aerosol species except COA (>20\%). Such weekend effects are quite different from those observed at other urban sites (Lough et al., 2006; Rattigan et al., 2010). For example, Rattigan et al. (2010) observed a significant weekend effect on EC, a tracer for primary emissions from traffic, at the South Bronx, New York, due to the reduced traffic activities on weekends. However, HOA in our study did not show similar behavior to EC in New York. The weak weekly cycles of POA species, e.g., HOA, indicate that the overall human activities appear not to be significantly reduced during weekends. For example, while $\sim 20 \%$ of private cars are not allowed to drive in the city during weekdays, there are no restrictions during weekends. As a result, the number of cars driving on the road in Beijing during weekdays and weekends might not be significantly different. This is consistent with a previous study in Beijing by Han et al. (2009) in which EC shows very similar diurnal profiles between weekdays and weekends. It should be noted that Wednesday shows the lowest concentration during the week. This is also different from a previous study in urban areas in eastern China, where the $\mathrm{PM}_{10}$ presented a gradual accumulation till midweek, then followed by a reduction, with the lowest concentration appearing during weekends (Gong et al., 2007). After checking the day-of-week meteorology, we found that the lowest concentration on Wednesday is primarily caused by the low RH and high wind speed (Fig. S3). During wintertime, the air masses often alternate rapidly between the south and the northwest, leading to a change between clean periods and pollution episodes within a few hours. Coincidently, the number of clean days that occurred on a Wednesday is the highest ( $\sim 6$ days). However, the day-of-week variations of aerosol species after excluding the data of clean periods are somewhat different (Fig. S4). The weekdays show slightly higher concentrations than weekends, but the overall day-ofweek variations are flat. The results suggest that meteorology is an important factor affecting the day-of-week pattern of aerosol species during wintertime.

The diurnal cycles of aerosol species and OA components between weekdays and weekends are shown in Fig. 6c. All aerosol species show overall similar diurnal cycles between weekdays and weekends. It is interesting to note that higher concentrations before 12:00 were observed during weekdays, while it is reversed after 16:00. This appears to be consistent with the reduced human activities in the morning on weekends. After excluding the influences of clean episodes, all aerosol species except COA present larger differences between weekdays and weekends before 12:00, yet close concentrations after 16:00 (Fig. S4c). Results here indicate that the weekend effects during wintertime in Beijing mainly occur in the first half of the day. The minor weekend effects on COA suggest that COA remains an important OA source throughout the whole week, contributing $17-22 \%$ of OA.
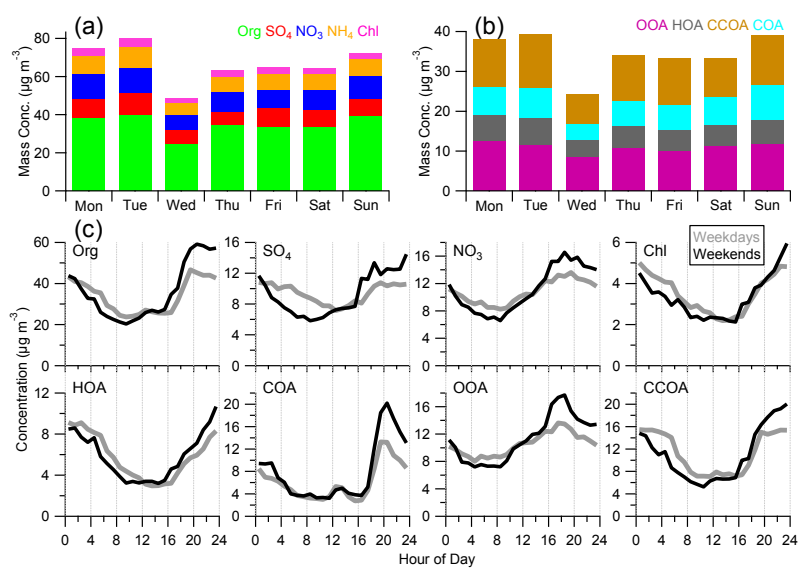

Fig. 6. Day-of-week variations of (a) NR-PM 1 chemical composition and (b) OA composition for the entire study. (c) shows a comparison of the diurnal variations of $\mathrm{NR}-\mathrm{PM}_{1}$ species and OA components between weekdays and weekends.

\subsection{Chemically resolved PM pollution}

Figure 7 shows the variations of mass concentrations and mass fractions of inorganic species and OA components as a function of NR-PM 1 mass loading. All aerosol species except COA and OOA show monotonic and almost linear increase with the increase of PM loading, yet the increasing rates vary for different aerosol species. For example, for an increase of $100 \mu \mathrm{g} \mathrm{m}^{-3}$ NR-PM 1 mass, sulfate presents the largest mass increase $\left(17.8 \mu \mathrm{g} \mathrm{m}^{-3}\right)$ followed by nitrate $\left(14.4 \mu \mathrm{g} \mathrm{m}^{-3}\right)$, ammonium $\left(12.3 \mu \mathrm{g} \mathrm{m}^{-3}\right)$, and chloride $\left(5.5 \mu \mathrm{g} \mathrm{m}^{-3}\right)$. The OOA increases linearly below $\sim 140 \mu \mathrm{g} \mathrm{m}^{-3}$, and then remains relatively stable at higher mass loading, which might suggest the limited formation of secondary OA during periods with high PM pollution in winter. Although the mass concentrations of aerosol species vary significantly as a function of PM loading, the contribution of total OA and inorganic species to the total NR-PM 1 mass did not show clear PM-mass loading dependency, which indicates that the high PM pollution in winter is a result of synergistic effects of all pollutants. As organics shows the dominant contribution ( 50-60\%) to PM pollution across different mass loadings, inorganic species, i.e., sulfate, nitrate, and ammonium, contribute $\sim 10-15 \%$ each to the total NR-PM 1 mass (Fig. $7 b$ ). This mass-loading-dependent aerosol composition is quite different from that observed in summer, particularly nitrate (Sun et al., 2012). In summer, the nitrate contribution shows a significant increase as a function of PM loading, highlighting the important role of nitrate in PM pollution. However, the wintertime nitrate shows a rather stable and even a slight decrease of contribution as PM mass loading increases. The different photochemical production rate, $\mathrm{RH}$ and temperature influences on gas-particle partitioning (Hennigan et al., 2009; Ranjan et al., 2012), as well as $\mathrm{NH}_{3}$ ambient levels 


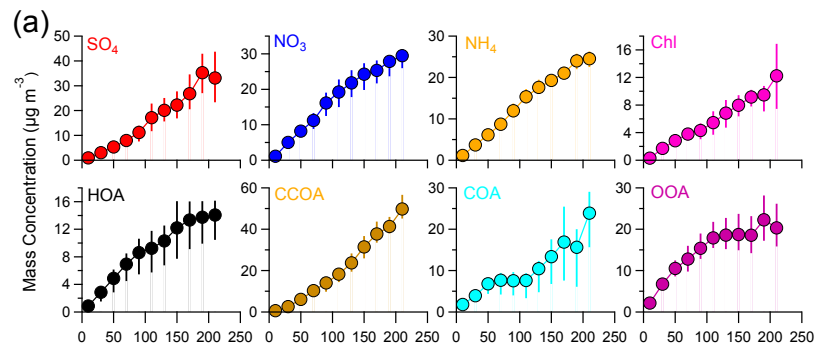

(b)

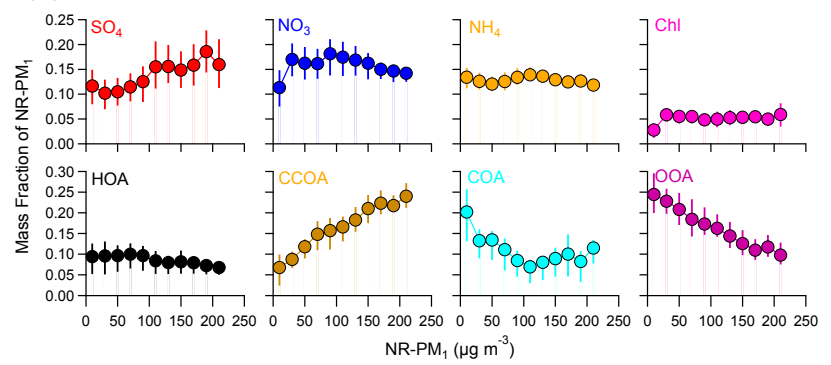

Fig. 7. Variations of (a) mass concentrations and (b) mass fractions of NR-PM ${ }_{1}$ species and OA components as a function of NR-PM mass loadings. The data were binned according to the total NR-PM mass, and the vertical lines are 25th (bottom) and 75th percentiles (top).

(Meng et al., 2011), are all potential causes of such seasonal differences. The sulfate contribution shows a slight increase from $\sim 10-19 \%$, indicating addition production of sulfate mass during high PM episodes. The increase of additional sulfate mass is likely from aqueous production rather than photochemical production, given that nitrate did not show a corresponding increase with sulfate. Indeed, the elevated PM levels in winter are also positively related to RH (Sun et al., 2013), which would facilitate the aqueous processing of $\mathrm{SO}_{2}$ to form sulfate.

The OA components vary very widely as a function of PM mass loading. Despite the wide concentration range of $\mathrm{PM}$, the contributions of HOA and COA to NR-PM 1 are between $\sim 5-10 \%$ and $\sim 10-15 \%$, respectively, and the variations are relatively small across all mass loadings. However, CCOA and OOA show a dramatic and reversed PMloading dependency. The contribution of CCOA to NR-PM increases significantly from $\sim 5 \%$ to $25 \%$ as the NR-PM mass varies from $\sim 10 \mu \mathrm{g} \mathrm{m}^{-3}$ to more than $200 \mu \mathrm{g} \mathrm{m}^{-3}$. The contribution of OOA, however, decreases from $\sim 25 \%$ to $10 \%$. The results suggest that CCOA plays an important role in causing high PM pollution in wintertime, while the role of OOA is less significant. Considering that CCOA is the major component emitted from coal combustion, the results here confirm that coal combustion is a major source of fine PM during wintertime.

The relationship between SOA and POA, and their roles in the PM pollution in summer in Beijing were reported in Sun et al. (2012). High PM pollution in summer is primarily as-
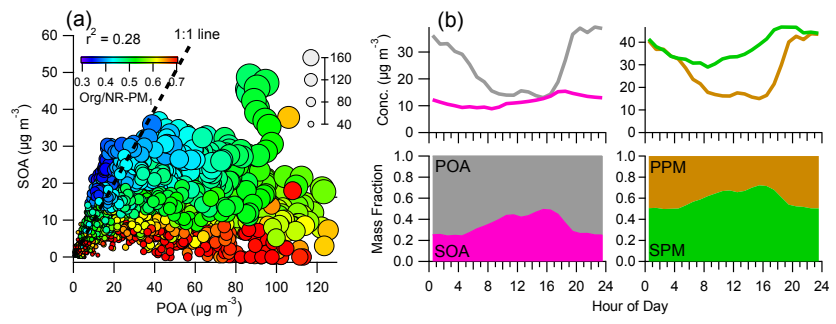

Fig. 8. (a) Relationship between SOA and POA. The data are colorcoded by the mass fraction of organics in the total NR-PM 1 , and the maker size is proportional to the NR-PM 1 mass loading. (b) Diurnal variations of mass concentrations and mass fractions for $\mathrm{SOA}$ and POA $(=\mathrm{HOA}+\mathrm{COA}+\mathrm{CCOA})$, and $\mathrm{SPM}\left(=\mathrm{SO}_{4}+\right.$ $\left.\mathrm{NO}_{3}+\mathrm{NH}_{4}+\mathrm{OOA}\right)$ and PPM $(=\mathrm{POA}+\mathrm{Chl})$.

sociated with secondary species. The scatterplot of SOA vs. $\mathrm{POA}(=\mathrm{HOA}+\mathrm{COA}+\mathrm{CCOA})$ shows very different behavior in winter, though a similar weak correlation between SOA and POA $\left(r^{2}=0.28\right)$ was observed in the two seasons. As shown in Fig. 8a, POA dominates OA most of time, and the HOA contribution is even more dominant when the OA mass fraction in NR-PM 1 is higher. For example, when the mass fraction of $\mathrm{OA}$ is $>\sim 65 \%$, the POA concentration can reach $\sim 120 \mu \mathrm{g} \mathrm{m}^{-3}$, while SOA is generally below $10 \mu \mathrm{g} \mathrm{m}^{-3}$, indicating that POA is more than 10 times higher than SOA. Even in the periods with the highest PM loadings, POA exceeds SOA most of time, yet with a relatively low OA mass fraction, $\sim 40-65 \%$. The diurnal cycles of POA and SOA in Fig. $8 \mathrm{~b}$ further show that POA exceeds SOA throughout the day, accounting for $51-76 \%$ of OA. We also note that SOA shows an elevated contribution, from $\sim 25 \%$ to $49 \%$ during daytime due to photochemical production. Overall, the average concentration of POA and SOA in winter is 23.7 and $10.7 \mu \mathrm{g} \mathrm{m}^{-3}$, accounting for $69 \%$ and $31 \%$, respectively, of OA. While the SOA concentration between summer and winter is close, the POA in winter is more than 3 times higher than that in summer (Table 1). Results above demonstrate the different impacts of SOA and POA on PM pollution in different seasons. While SOA is of importance in summer, POA plays a more important role in winter. The roles of total primary and secondary species in PM pollution in winter were also investigated. The diurnal variations of secondary $\mathrm{PM}\left(\mathrm{SPM}=\mathrm{SO}_{4}+\mathrm{NO}_{3}+\mathrm{NH}_{4}+\mathrm{OOA}\right)$ and primary PM $(\mathrm{PPM}=\mathrm{HOA}+\mathrm{COA}+\mathrm{CCOA}+\mathrm{Chl})$ are shown in Fig. $8 \mathrm{~b}$. Chloride is classified into PPM because it is mainly from the direct emission of coal combustion in winter. While SPM and PPM both present pronounced diurnal cycles, SPM shows higher mass loading than PPM during daytime $(\sim 06: 00-$ 20:00), yet comparable to PPM at night. The contribution of SPM to the total NR-PM 1 varies from 50-72\%, with the highest contribution occurring at 15:00-16:00. The average contribution of SPM and PPM for the entire study was $59 \%$ and $41 \%$, respectively. Therefore, results above suggest that 


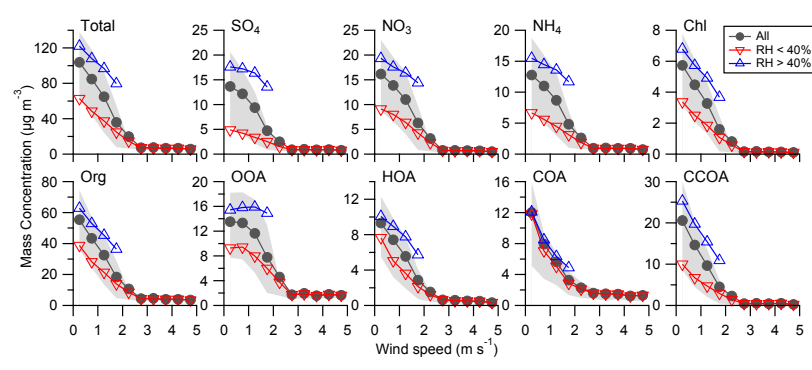

Fig. 9. Variations of NR-PM $M_{1}$ species and OA components as a function of wind speed. The data were further categorized into two groups with a RH threshold of $40 \%$. The top and bottom of shaded areas are 25 th and 75 th percentiles.

SPM is also important in PM pollution during wintertime although POA overwhelms SOA in OA.

\subsection{Meteorological effects on PM evolution}

Meteorology affects PM evolution in many ways, e.g., accumulation or dilution, gas-particle partitioning, and secondary formation. Here we mainly explored the influences of wind speed, humidity and temperature on PM evolution during wintertime. Figure 9 shows the variations of mass concentra-

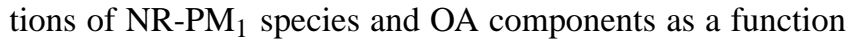
of wind speed. All aerosol species show a rapid and almost linear decrease with a reduction rate of $\sim 30 \%$ per m s$^{-1}$ at wind speed $<3 \mathrm{~m} \mathrm{~s}^{-1}$. When wind speed is $>3 \mathrm{~m} \mathrm{~s}^{-1}$, the total NR-PM 1 mass loading quickly drops from $\sim 100 \mu \mathrm{g} \mathrm{m}^{-3}$ to $<10 \mu \mathrm{g} \mathrm{m}^{-3}$; at the same time, all aerosol species show very low concentrations, generally $<2 \mu \mathrm{g} \mathrm{m}^{-3}$. Similar wind speed dependency of EC was also observed in all seasons in Beijing (Han et al., 2009). These results suggest that winds are very efficient in cleaning up the PM pollution during wintertime. To further investigate the dilution effects of wind speed, the relationship between aerosol species and wind speed was separated into two groups with $\mathrm{RH}<40 \%$ and $>40 \%$. As shown in Fig. 9, the RH-separated relationship varies differently to some extent for the primary and secondary species. The secondary species, e.g., sulfate and OOA, show relatively weaker wind speed dependency in comparison to POA components at high RH. Also note the wind dependency of POA components, e.g., HOA and COA, show smaller differences between low and high RH values than secondary species, elucidating the different impacts of $\mathrm{RH}$ on processing aerosol species with different hygroscopicities.

The RH effects on aerosol processing were illustrated by the correlations between $\mathrm{NO}_{3}$ and $\mathrm{SO}_{4}$, and the ratio of $\mathrm{NO}_{3} / \mathrm{SO}_{4}$ as a function of RH (Fig. 10). Nitrate and sulfate correlate well in both summer $\left(r^{2}=0.61\right)$ and winter $\left(r^{2}=0.64\right)$, suggesting a common secondary nature of these two species. However, the correlations between nitrate and sulfate are strongly RH dependent, and this depen-

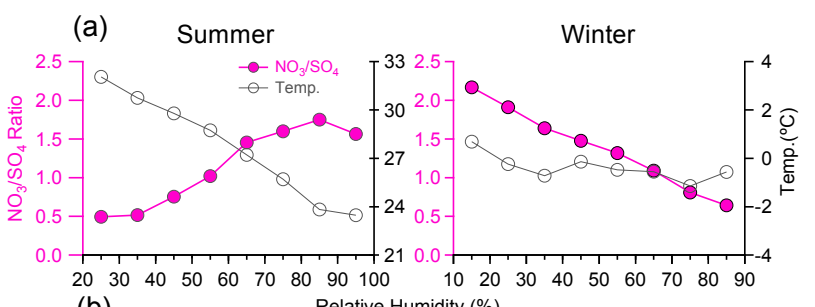

(b)

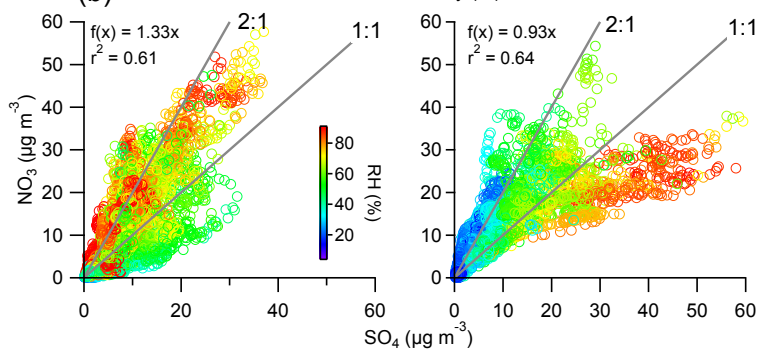

Fig. 10. (a) Variations of the ratio of $\mathrm{NO}_{3} / \mathrm{SO}_{4}$ and temperature as a function of $\mathrm{RH}$, and (b) correlations between $\mathrm{NO}_{3}$ and $\mathrm{SO}_{4}$ color-coded with RH in summer and winter.

dency is reversed between summer and winter. In summer, the $\mathrm{NO}_{3} / \mathrm{SO}_{4}$ ratio shows a positive correlation with $\mathrm{RH}$, indicating a faster growth rate of $\mathrm{NO}_{3}$ than $\mathrm{SO}_{4}$. As the $\mathrm{RH}$ varies from $\sim 20 \%$ to $>80 \%$, the $\mathrm{NO}_{3} / \mathrm{SO}_{4}$ ratio jumps from $\sim 0.5$ to $\sim 2.0$, which is a nearly 4-fold enhancement. As we reported in our previous study (Sun et al., 2012), the high concentration of nitrate at high RH is likely due to the transformation of $\mathrm{HNO}_{3}$ into aqueous phase, which could enhance the formation of nitrate particles, especially when there's excess gaseous ammonia in the atmosphere (Meng et al., 2011). As a comparison, the $\mathrm{NO}_{3} / \mathrm{SO}_{4}$ ratio in winter shows an opposite trend. The highest $\mathrm{NO}_{3} / \mathrm{SO}_{4}$ ratio of $\sim 2$ is observed at $\mathrm{RH}<\sim 20 \%$, and the ratio decreases linearly to $\sim 0.5$ when $\mathrm{RH}$ is above $80 \%$. Such differences for the $\mathrm{NO}_{3} / \mathrm{SO}_{4}$ ratio between summer and winter are indications of different formation mechanisms of nitrate and sulfate. As shown in Fig. 10, the RH-binned temperature in winter is generally below $2{ }^{\circ} \mathrm{C}$, and relatively constant across different RH values. Under these conditions, most nitrate would be expected in the particle phase, and the gasparticle partitioning would not play a significant role. Thus daytime photochemical production is the major formation mechanism for nitrate in winter. In contrast, high concentration of sulfate is mainly observed during several fog events with high RH (e.g., 2, 5-7, 13 December and 7-10 January in Fig. 1), indicating that fog processing might be the dominant pathway for the sulfate formation. To support this, we plot the correlations of $\Delta \mathrm{SO}_{2}$ versus $\Delta \mathrm{SO}_{4}^{2-}$ in Fig. 11. $\Delta \mathrm{SO}_{2}$ and $\Delta \mathrm{SO}_{4}^{2-}$ are the mass concentrations after subtracting the background concentration of $\mathrm{SO}_{2}$ and $\mathrm{SO}_{4}^{2-}$, i.e., $7 \mathrm{ppb}$ and $0.33 \mu \mathrm{g} \mathrm{m}^{-3}$, respectively, in this study. Again, the relationship of $\Delta \mathrm{SO}_{2}$ vs. $\Delta \mathrm{SO}_{4}^{2-}$ shows a strong RH dependency. 

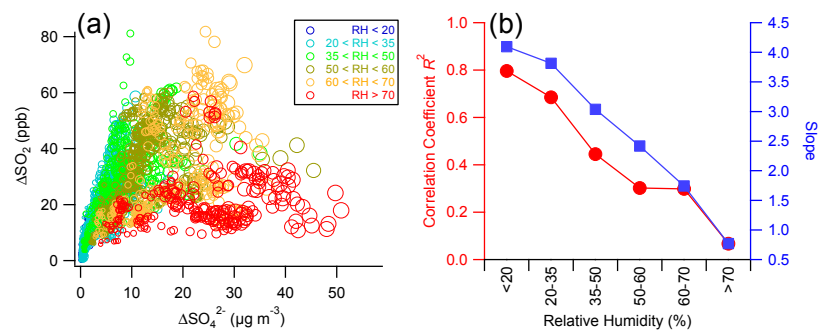

Fig. 11. (a) Scatter plots of $\Delta \mathrm{SO}_{2}$ versus $\Delta \mathrm{SO}_{4}^{2-}$ at different $\mathrm{RH}$ ranges, and (b) shows the linear regression coefficient $\left(R^{2}\right)$ and slope as a function of RH.

As RH is below $35 \%, \Delta \mathrm{SO}_{2}$ and $\Delta \mathrm{SO}_{4}^{2-}$ show tight correlation $\left(R^{2}>0.6\right)$, yet the majority of $\mathrm{SO}_{2}$ remains unoxidized. As $\mathrm{RH}$ increases, the concentration of $\Delta \mathrm{SO}_{2}$ starts to decrease, and the concentration of $\Delta \mathrm{SO}_{4}^{2-}$ correspondingly increases. The correlation between $\Delta \mathrm{SO}_{2}$ and $\Delta \mathrm{SO}_{4}^{2-}$ is thus sharply reduced, yet with more $\mathrm{SO}_{2}$ being oxidized to sulfate. Aqueous-phase oxidation of $\mathrm{SO}_{2}$ can be very fast, and the oxidation rates depend on the fog droplet $\mathrm{pH}$ and oxidants (e.g., $\mathrm{H}_{2} \mathrm{O}_{2}, \mathrm{O}_{3}$, and $\mathrm{O}_{2} / \mathrm{Fe} / \mathrm{Mn}$ ) (Reilly et al., 2001; Seinfeld and Pandis, 2006). While $\mathrm{H}_{2} \mathrm{O}_{2}$ is the most important oxidant at low $\mathrm{pH}\left(\right.$ e.g., $\mathrm{pH}<5$ ), $\mathrm{O}_{3}$ plays more important roles in oxidation of $\mathrm{SO}_{2}$ at high $\mathrm{pH}$ (e.g., $\mathrm{pH}>5$ ) (Shen et al., 2012). The rapid fog processing of $\mathrm{SO}_{2}$ was also observed in the North China Plain (Zhang and Tie, 2011); however, the dominant oxidation pathway is not known yet because of the absence of fog $\mathrm{pH}$ measurements. Despite this, our results suggest that aqueous processing, mostly fog processing in this study, has played a significant role in the formation of sulfate.

Figure 12 shows the variations of NR-PM 1 species and OA as a function of temperature. HOA shows similar and monotonically decreasing trend with the increase of temperature at different RH ranges, suggesting a negative influence of temperature on primary traffic emissions. Ranjan et al. (2012) found that the gas-particle partitioning of POA from diesel engines is dependent on temperature, and increasing temperature would decrease the emission factor of POA. Similarly, a study by Nam et al. (2010) also found that decrease of temperature can exponentially increase the PM emissions from light-duty vehicles. The results above are consistent with the temperature-dependent POA concentration in this study. Compared to $\mathrm{HOA}, \mathrm{NO}_{3}$ and $\mathrm{OOA}$ show an increasing trend when temperature increases. This appears to conflict with temperature-dependent gas-particle partitioning. However, as shown in Fig. 3, high temperature on one day usually appears in the afternoon when photochemistry is the most intense. Results here indicate that the photochemical production of $\mathrm{NO}_{3}$ and OOA overcomes gas-particle partitioning under overall low ambient temperatures $\left(<12^{\circ} \mathrm{C}\right)$ during wintertime. Other aerosol species appear to show different temperature-dependent behaviors between low and high

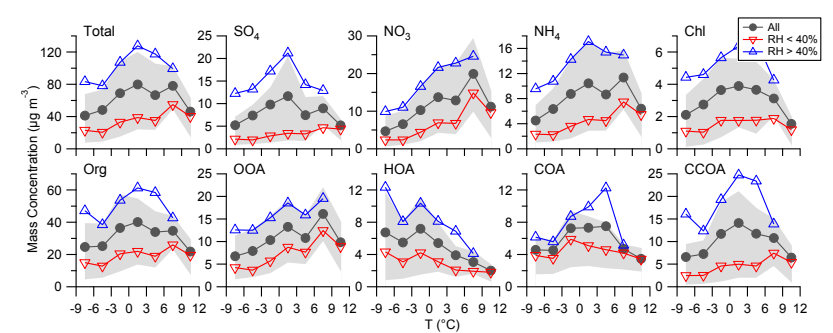

Fig. 12. Variations of NR-PM 1 species and OA components as a function of temperature. The data were further categorized into two groups with a RH threshold of $40 \%$. The top and bottom of shaded areas are 25 th and 75 th percentiles.

RH. The mass concentrations of most aerosol species peak at temperature of $\sim 0-3{ }^{\circ} \mathrm{C}$ when $\mathrm{RH}$ is higher than $40 \%$; comparatively, most of them show a slow increasing trend with the increase of temperature when RH is below $40 \%$.

\section{Conclusions}

We have a detailed characterization of wintertime aerosol particle composition and sources in the megacity of Beijing, China. The NR-PM 1 species including organics, sulfate, nitrate, ammonium, and chloride were measured in situ from 21 November 2011 to 20 January 2012 with an Aerodyne ACSM. The submicron mass varies very dynamically with an average concentration of $67 \pm 55 \mu \mathrm{g} \mathrm{m}^{-3}$ for the entire study. Similar to summer, organics comprises the major fraction of NR-PM $M_{1}$ in winter. However, the contributions of organics and chloride to NR-PM 1 are significantly enhanced during wintertime, increasing from $40 \%$ to $52 \%$ and $1 \%$ to $5 \%$ for organics and chloride, respectively. All NR-PM 1 aerosol species show quite different diurnal behaviors between summer and winter due to different source emissions and chemical processing. In particular, the wintertime nitrate shows a gradual increase from early morning to late afternoon, and also correlates well with SOA formation, indicating that photochemical production dominates the formation mechanisms of nitrate at low ambient temperatures.

PMF analysis was performed on ACSM mass spectra to investigate the sources and processes of $\mathrm{OA}$ during wintertime. Four components were identified including three POA factors that are associated with traffic (HOA), cooking (COA), and coal combustion (CCOA) emissions and one secondary factor OOA. All POA components present pronounced diurnal cycles, with the highest concentrations occurring at night. OOA, however, presents a diurnal cycle as a result of photochemical processing. The POA dominates OA composition during the heating season, on average accounting for $69 \%$, and plays a more important role in PM pollution compared to OOA. Among POA components, CCOA is the major primary source, contributing $33 \%$ of OA. CCOA also plays a key role in chemically resolved PM pollution during wintertime as its 
contribution increases linearly as a function of to the total NR-PM $\mathrm{P}_{1}$ mass. As a comparison, the OOA concentration remains relatively stable at high PM loadings, and its contribution to the total NR-PM 1 decreases with the increase of PM pollution, which might indicate the limited SOA formation during high PM pollution episodes.

Meteorology is also important in PM pollution and aerosol processing in winter. Our results show that winds can clean up the PM pollution efficiently. When the ground wind speed is $>\sim 3 \mathrm{~m} \mathrm{~s}^{-1}$, the mass concentrations of all aerosol species quickly drop to $<\sim 2 \mu \mathrm{g} \mathrm{m}^{-3}$. Note that the cleaning effects of winds appear to be slightly different for primary and secondary species at high RH periods. The relative humidity shows very different impacts on nitrate and sulfate processes between summer and winter. In summer, high humidity leads to a faster growth of nitrate, likely due to the transformation of $\mathrm{HNO}_{3}$ to ammonium nitrate with access $\mathrm{NH}_{3}$ in the atmosphere. However, the humidity in winter shows a stronger effect on sulfate formation. In fact, the periods with high humidity in this study are often associated with fog events; therefore, fog processing of high concentration of precursor $\mathrm{SO}_{2}$ to form sulfate might be the major cause. The temperature-dependent aerosol composition highlights the increased PM emissions from vehicles at lower temperatures.

\section{Supplementary material related to this article is available online at: http://www.atmos-chem-phys.net/13/ 4577/2013/acp-13-4577-2013-supplement.pdf.}

Acknowledgements. This work was supported by the National Key Project of Basic Research (2013CB955801), the National Natural Science Foundation of China (41175108, 40905068), and the Strategic Priority Research Program (B) of the Chinese Academy of Sciences (Grant No. XDB05020501). Additional support was provided by the Special Fund for Environmental Protection Research in the Public Interest (201009002) and Beijing Municipal Science and Technology Commission (D09040903670904). We thank the Technical and Service Center, Institute of Atmospheric Physics, Chinese Academy of Sciences for providing the meteorology data.

Edited by: X. Tie

\section{References}

Aiken, A. C., Salcedo, D., Cubison, M. J., Huffman, J. A., DeCarlo, P. F., Ulbrich, I. M., Docherty, K. S., Sueper, D., Kimmel, J. R., Worsnop, D. R., Trimborn, A., Northway, M., Stone, E. A., Schauer, J. J., Volkamer, R. M., Fortner, E., de Foy, B., Wang, J., Laskin, A., Shutthanandan, V., Zheng, J., Zhang, R., Gaffney, J., Marley, N. A., Paredes-Miranda, G., Arnott, W. P., Molina, L. T., Sosa, G., and Jimenez, J. L.: Mexico City aerosol analysis during MILAGRO using high resolution aerosol mass spectrometry at the urban supersite (T0) - Part 1: Fine particle composition and organic source apportionment, Atmos. Chem. Phys., 9, 6633-6653, doi:10.5194/acp-9-6633-2009, 2009.

Alfarra, M. R., Prevot, A. S. H., Szidat, S., Sandradewi, J., Weimer, S., Lanz, V. A., Schreiber, D., Mohr, M., and Baltensperger, U.: Identification of the mass spectral signature of organic aerosols from wood burning emissions, Environ. Sci. Technol., 41, 57705777, 2007.

Allan, J. D., Williams, P. I., Morgan, W. T., Martin, C. L., Flynn, M J., Lee, J., Nemitz, E., Phillips, G. J., Gallagher, M. W., and Coe, H.: Contributions from transport, solid fuel burning and cooking to primary organic aerosols in two UK cities, Atmos. Chem. Phys., 10, 647-668, doi:10.5194/acp-10-647-2010, 2010.

Canagaratna, M., Jayne, J., Jimenez, J. L., Allan, J. A., Alfarra, R., Zhang, Q., Onasch, T., Drewnick, F., Coe, H., Middlebrook, A., Delia, A., Williams, L., Trimborn, A., Northway, M., Kolb, C., Davidovits, P., and Worsnop, D.: Chemical and microphysical characterization of aerosols via Aerosol Mass Spectrometry, Mass Spectrom. Rev., 26, 185-222, 2007.

Canagaratna, M. R., Jayne, J. T., Ghertner, D. A., Herndon, S., Shi, Q., Jimenez, J. L., Silva, P. J., Williams, P., Lanni, T., Drewnick, F., Demerjian, K. L., Kolb, C. E., and Worsnop, D. R.: Chase studies of particulate emissions from in-use New York City vehicles, Aerosol Sci. Tech., 38, 555-573, 2004.

Canagaratna, M. R., Onasch, T. B., Wood, E. C., Herndon, S. C., Jayne, J. T., Cross, E. S., Miake-Lye, R. C., Kolb, C. E., and Worsnop, D. R.: Evolution of vehicle exhaust particles in the atmosphere, J. Air Waste Manage. Assoc., 60, 1192-1203, 2010.

Chan, C. K. and Yao, X.: Air pollution in mega cities in China, Atmos. Environ., 42, 1-42, doi:10.1016/j.atmosenv.2007.09.003, 2008.

Crippa, M., DeCarlo, P. F., Slowik, J. G., Mohr, C., Heringa, M. F., Chirico, R., Poulain, L., Freutel, F., Sciare, J., Cozic, J., Di Marco, C. F., Elsasser, M., Nicolas, J. B., Marchand, N., Abidi, E., Wiedensohler, A., Drewnick, F., Schneider, J., Borrmann, S., Nemitz, E., Zimmermann, R., Jaffrezo, J.-L., Prévôt, A. S. $\mathrm{H}$., and Baltensperger, U.: Wintertime aerosol chemical composition and source apportionment of the organic fraction in the metropolitan area of Paris, Atmos. Chem. Phys., 13, 961-981, doi:10.5194/acp-13-961-2013, 2013.

DeCarlo, P. F., Ulbrich, I. M., Crounse, J., de Foy, B., Dunlea, E. J., Aiken, A. C., Knapp, D., Weinheimer, A. J., Campos, T., Wennberg, P. O., and Jimenez, J. L.: Investigation of the sources and processing of organic aerosol over the Central Mexican Plateau from aircraft measurements during MILAGRO, Atmos. Chem. Phys., 10, 5257-5280, doi:10.5194/acp-10-52572010, 2010.

Docherty, K. S., Aiken, A. C., Huffman, J. A., Ulbrich, I. M., DeCarlo, P. F., Sueper, D., Worsnop, D. R., Snyder, D. C., Peltier, R. E., Weber, R. J., Grover, B. D., Eatough, D. J., Williams, B. J., Goldstein, A. H., Ziemann, P. J., and Jimenez, J. L.: The 2005 Study of Organic Aerosols at Riverside (SOAR-1): instrumental intercomparisons and fine particle composition, Atmos. Chem. Phys., 11, 12387-12420, doi:10.5194/acp-11-12387-2011, 2011.

Dong, H.-B., Zeng, L.-M., Hu, M., Wu, Y.-S., Zhang, Y.-H., Slanina, J., Zheng, M., Wang, Z.-F., and Jansen, R.: Technical Note: The application of an improved gas and aerosol collector for ambient air pollutants in China, Atmos. Chem. Phys., 12, 10519- 
10533, doi:10.5194/acp-12-10519-2012, 2012.

Du, H., Kong, L., Cheng, T., Chen, J., Du, J., Li, L., Xia, X., Leng, C., and Huang, G.: Insights into summertime haze pollution events over Shanghai based on online water-soluble ionic composition of aerosols, Atmos. Environ., 45, 5131-5137, doi:10.1016/j.atmosenv.2011.06.027, 2011.

Duan, F., He, K., Ma, Y., Jia, Y., Yang, F., Lei, Y., Tanaka, S., and Okuta, T.: Characteristics of carbonaceous aerosols in Beijing, China, Chemosphere, 60, 355-364, doi:10.1016/j.chemosphere.2004.12.035, 2005.

Eatough, D. J., Long, R. W., Modey, W. K., and Eatough, N. L.: Semi-volatile secondary organic aerosol in urban atmospheres: meeting a measurement challenge, Atmos. Environ., 37, 12771292, 2003.

Forster, P., Ramaswamy, V., Artaxo, P., Berntsen, T., Betts, R., Fahey, D. W., Haywood, J., Lean, J., Lowe, D. C., Myhre, G., Nganga, J., Prinn, R., Raga, G., Schulz, M., and Dorland, R. V.: Changes in Atmospheric Constituents and in Radiative Forcing., in: Climate Change 2007: The Physical Science Basis. Contribution of Working Group I to the Fourth Assessment Report of the Intergovernmental Panel on Climate Change, edited by: Solomon, S., Qin, D., Manning, M., Chen, Z., Marquis, M., Averyt, K. B., Tignor, M., and Miller, H. L., Cambridge University Press, Cambridge, United Kingdom and New York, NY, USA, 2007.

Ge, X., Setyan, A., Sun, Y., and Zhang, Q.: Primary and secondary organic aerosols in Fresno, California during wintertime: Results from high resolution aerosol mass spectrometry, J. Geophys. Res., 117, D19301, doi:10.1029/2012JD018026, 2012.

Gong, D.-Y., Ho, C.-H., Chen, D., Qian, Y., Choi, Y.-S., and Kim, J.: Weekly cycle of aerosol-meteorology interaction over China, J. Geophys. Res., 112, D22202, doi:10.1029/2007jd008888, 2007.

Han, S., Kondo, Y., Oshima, N., Takegawa, N., Miyazaki, Y., Hu, M., Lin, P., Deng, Z., Zhao, Y., Sugimoto, N., and Wu, Y.: Temporal variations of elemental carbon in Beijing, J. Geophys. Res., 114, D23202, doi:23210.21029/22009JD012027, 2009.

He, K., Yang, F., Ma, Y., Zhang, Q., Yao, X., Chan, C. K., Cadle, S., Chan, T., and Mulawa, P.: The characteristics of $\mathrm{PM}_{2.5}$ in Beijing, China, Atmos. Environ., 35, 4959-4970, Doi: 10.1016/s1352-2310(01)00301-6, 2001.

He, L.-Y., Lin, Y., Huang, X.-F., Guo, S., Xue, L., Su, Q., Hu, M., Luan, S.-J., and Zhang, Y.-H.: Characterization of highresolution aerosol mass spectra of primary organic aerosol emissions from Chinese cooking and biomass burning, Atmos. Chem. Phys., 10, 11535-11543, doi:10.5194/acp-10-11535-2010, 2010.

Hennigan, C. J., Bergin, M. H., Dibb, J. E., and Weber, R. J.: Enhanced secondary organic aerosol formation due to water uptake by fine particles, Geophys. Res. Lett., 35, L18801, doi:18810.11029/12008GL035046, 2008.

Hennigan, C. J., Bergin, M. H., Russell, A. G., Nenes, A., and Weber, R. J.: Gas/particle partitioning of water-soluble organic aerosol in Atlanta, Atmos. Chem. Phys., 9, 3613-3628, doi:10.5194/acp-9-3613-2009, 2009.

Huang, X.-F., He, L.-Y., Hu, M., Canagaratna, M. R., Sun, Y., Zhang, Q., Zhu, T., Xue, L., Zeng, L.-W., Liu, X.-G., Zhang, Y.-H., Jayne, J. T., Ng, N. L., and Worsnop, D. R.: Highly time-resolved chemical characterization of atmospheric submicron particles during 2008 Beijing Olympic Games using an Aerodyne High-Resolution Aerosol Mass Spectrometer, Atmos.
Chem. Phys., 10, 8933-8945, doi:10.5194/acp-10-8933-2010, 2010.

Jimenez, J. L., Canagaratna, M. R., Donahue, N. M., Prevot, A. S. H., Zhang, Q., Kroll, J. H., DeCarlo, P. F., Allan, J. D., Coe, H., Ng, N. L., Aiken, A. C., Docherty, K. S., Ulbrich, I. M., Grieshop, A. P., Robinson, A. L., Duplissy, J., Smith, J. D., Wilson, K. R., Lanz, V. A., Hueglin, C., Sun, Y. L., Tian, J., Laaksonen, A., Raatikainen, T., Rautiainen, J., Vaattovaara, P., Ehn, M., Kulmala, M., Tomlinson, J. M., Collins, D. R., Cubison, M. J., E, Dunlea, J., Huffman, J. A., Onasch, T. B., Alfarra, M. R., Williams, P. I., Bower, K., Kondo, Y., Schneider, J., Drewnick, F., Borrmann, S., Weimer, S., Demerjian, K., Salcedo, D., Cottrell, L., Griffin, R., Takami, A., Miyoshi, T., Hatakeyama, S., Shimono, A., Sun, J. Y., Zhang, Y. M., Dzepina, K., Kimmel, J. R., Sueper, D., Jayne, J. T., Herndon, S. C., Trimborn, A. M., Williams, L. R., Wood, E. C., Middlebrook, A. M., Kolb, C. E., Baltensperger, U., and Worsnop, D. R.: Evolution of organic aerosols in the atmosphere, Science, 326, 1525-1529, doi:10.1126/science.1180353, 2009.

Kroll, J. H., Smith, J. D., Worsnop, D. R., and Wilson, K. R.: Characterisation of lightly oxidised organic aerosol formed from the photochemical aging of diesel exhaust particles, Environmental Chemistry, 9, 211-220, doi:10.1071/EN11162, 2012.

Liu, Q.: Physical and chemical characteristics of submicron aerosol and its sources in Beijing, LAPC, Institute of Atmospheric Physics, Chinese Academy of Sciences, 2012.

Liu, Q., Sun, Y., Hu, B., Liu, Z., Akio, S., and Wang, Y.: In situ measurement of PM1 organic aerosol in Beijing winter using a high-resolution aerosol mass spectrometer, Chin. Sci. Bull., 57, 819-826, doi:10.1007/s11434-011-4886-0, 2012.

Lough, G. C., Schauer, J. J., Lonneman, W. A., and Allen, M. K.: Summer and winter nonmethane hydrocarbon emissions from on-road motor vehicles in the Midwestern United States, J. Air Waste Manage. Assoc., 55, 629-646, 2005.

Lough, G. C., Schauer, J. J., and Lawson, D. R.: Dayof-week trends in carbonaceous aerosol composition in the urban atmosphere, Atmos. Environ., 40, 4137-4149, doi:10.1016/j.atmosenv.2006.03.009, 2006.

Massoli, P., Fortner, E. C., Canagaratna, M. R., Williams, L. R., Zhang, Q., Sun, Y., Schwab, J. J., Trimborn, A., Onasch, T. B., Demerjian, K. L., Kolb, C. E., Worsnop, D. R., and Jayne, J. T.: Pollution Gradients and Chemical Characterization of Particulate Matter from Vehicular Traffic Near Major Roadways: Results from the 2009 Queens College Air Quality Study in NYC, Aerosol Sci. Tech., 46, 1201-1218, doi:10.1080/02786826.2012.701784, 2012.

Matthew, B. M., Middlebrook, A. M., and Onasch, T. B.: Collection Efficiencies in an Aerodyne Aerosol Mass Spectrometer as a Function of Particle Phase for Laboratory Generated Aerosols, Aerosol Sci. Tech., 42, 884-898, 2008.

McLafferty, F. W. and Turecek, F.: Interpretation of Mass Spectra, University Science Books, Mill Valley, California, 1993.

Meng, Z. Y., Lin, W. L., Jiang, X. M., Yan, P., Wang, Y., Zhang, Y. M., Jia, X. F., and Yu, X. L.: Characteristics of atmospheric ammonia over Beijing, China, Atmos. Chem. Phys., 11, 61396151, doi:10.5194/acp-11-6139-2011, 2011.

Middlebrook, A. M., Bahreini, R., Jimenez, J. L., and Canagaratna, M. R.: Evaluation of Composition-Dependent Collection Efficiencies for the Aerodyne Aerosol Mass Spectrometer using 
Field Data, Aerosol Sci. Tech., 46, 258-271, 2012.

Mohr, C., Huffman, J. A., Cubison, M. J., Aiken, A. C., Docherty, K. S., Kimmel, J. R., Ulbrich, I. M., Hannigan, M., and Jimenez, J. L.: Characterization of primary organic aerosol emissions from meat cooking, trash burning, and motor vehicles with HighResolution Aerosol Mass Spectrometry and comparison with ambient and chamber observations, Environ. Sci. Technol., 43, 2443-2449, doi:10.1021/es8011518, 2009.

Mohr, C., DeCarlo, P. F., Heringa, M. F., Chirico, R., Slowik, J. G., Richter, R., Reche, C., Alastuey, A., Querol, X., Seco, R., Peñuelas, J., Jiménez, J. L., Crippa, M., Zimmermann, R., Baltensperger, U., and Prévôt, A. S. H.: Identification and quantification of organic aerosol from cooking and other sources in Barcelona using aerosol mass spectrometer data, Atmos. Chem. Phys., 12, 1649-1665, doi:10.5194/acp-12-1649-2012, 2012.

Molina, M. J. and Molina, L. T.: Megacities and atmospheric pollution, J. Air Waste Manage. Assoc., 54, 644-680, 2004.

Molina, L. T., Madronich, S., Gaffney, J. S., Apel, E., de Foy, B., Fast, J., Ferrare, R., Herndon, S., Jimenez, J. L., Lamb, B., Osornio-Vargas, A. R., Russell, P., Schauer, J. J., Stevens, P. S., Volkamer, R., and Zavala, M.: An overview of the MILAGRO 2006 Campaign: Mexico City emissions and their transport and transformation, Atmos. Chem. Phys., 10, 8697-8760, doi:10.5194/acp-10-8697-2010, 2010.

Nam, E., Kishan, S., Baldauf, R. W., Fulper, C. R., Sabisch, M., and Warila, J.: Temperature Effects on Particulate Matter Emissions from Light-Duty, Gasoline-Powered Motor Vehicles, Environ. Sci. Technol., 44, 4672-4677, doi:10.1021/es100219q, 2010.

Ng, N. L., Canagaratna, M. R., Zhang, Q., Jimenez, J. L., Tian, J., Ulbrich, I. M., Kroll, J. H., Docherty, K. S., Chhabra, P. S., Bahreini, R., Murphy, S. M., Seinfeld, J. H., Hildebrandt, L., Donahue, N. M., DeCarlo, P. F., Lanz, V. A., Prévôt, A. S. H., Dinar, E., Rudich, Y., and Worsnop, D. R.: Organic aerosol components observed in Northern Hemispheric datasets from Aerosol Mass Spectrometry, Atmos. Chem. Phys., 10, 46254641, doi:10.5194/acp-10-4625-2010, 2010.

Ng, N. L., Canagaratna, M. R., Jimenez, J. L., Zhang, Q., Ulbrich, I. M., and Worsnop, D. R.: Real-Time Methods for Estimating Organic Component Mass Concentrations from Aerosol Mass Spectrometer Data, Environ. Sci. Technol., 45, 910-916, doi:10.1021/es102951k, 2011a.

Ng, N. L., Herndon, S. C., Trimborn, A., Canagaratna, M. R., Croteau, P. L., Onasch, T. B., Sueper, D., Worsnop, D. R., Zhang, Q., Sun, Y. L., and Jayne, J. T.: An Aerosol Chemical Speciation Monitor (ACSM) for Routine Monitoring of the Composition and Mass Concentrations of Ambient Aerosol, Aerosol Sci. Tech., 45, 770-784, 2011b.

Paatero, P. and Tapper, U.: Positive matrix factorization: A nonnegative factor model with optimal utilization of error estimates of data values, Environmetrics, 5, 111-126, 1994.

Pope III, C. A., Burnett, R. T., Thun, M. J., Calle, E. E., Krewski, D., Ito, K., and Thurston, G. D.: Lung cancer, cardiopulmonary mortality, and long-term exposure to fine particulate air pollution, JAMA-J. Am. Med. Assoc., 287, 1132-1141, 2002.

Ranjan, M., Presto, A. A., May, A. A., and Robinson, A. L.: Temperature Dependence of Gas-Particle Partitioning of Primary Organic Aerosol Emissions from a Small Diesel Engine, Aerosol Sci. Tech., 46, 13-21, 2012.
Rattigan, O. V., Felton, H. D., Bae, M.-S., Schwab, J. J., and Demerjian, K. L.: Multi-year hourly $\mathrm{PM}_{2.5}$ carbon measurements in New York: Diurnal, day of week and seasonal patterns, Atmos. Environ., 44, 2043-2053, 2010.

Reilly, J. E., Rattigan, O. V., Moore, K. F., Judd, C., Sherman, D. E., Dutkiewicz, V. A., Kreidenweis, S. M., Husain, L., and Collett Jr., J. L.: Drop size-dependent S(IV) oxidation in chemically heterogeneous radiation fogs, Atmos. Environ., 35, 5717-5728, 2001.

Salcedo, D., Onasch, T. B., Dzepina, K., Canagaratna, M. R., Zhang, Q., Huffman, J. A., DeCarlo, P. F., Jayne, J. T., Mortimer, P., Worsnop, D. R., Kolb, C. E., Johnson, K. S., Zuberi, B., Marr, L. C., Volkamer, R., Molina, L. T., Molina, M. J., Cardenas, B., Bernabé, R. M., Márquez, C., Gaffney, J. S., Marley, N. A., Laskin, A., Shutthanandan, V., Xie, Y., Brune, W., Lesher, R., Shirley, T., and Jimenez, J. L.: Characterization of ambient aerosols in Mexico City during the MCMA-2003 campaign with Aerosol Mass Spectrometry: results from the CENICA Supersite, Atmos. Chem. Phys., 6, 925-946, doi:10.5194/acp-6-925-2006, 2006.

Seinfeld, J. H. and Pandis, S. N.: Atmospheric Chemistry and Physics: from Air Pollution to Climate Change, Wiley, John \& Sons, Incorporated, New York, 1203 pp., 2006

Shen, X., Lee, T., Guo, J., Wang, X., Li, P., Xu, P., Wang, Y., Ren, Y., Wang, W., Wang, T., Li, Y., Carn, S. A., and Collett Jr, J. L.: Aqueous phase sulfate production in clouds in eastern China, Atmos. Environ., 62, 502-511, doi:10.1016/j.atmosenv.2012.07.079, 2012

Song, Y., Zhang, Y., Xie, S., Zeng, L., Zheng, M., Salmon, L. G. Shao, M., and Slanina, S.: Source apportionment of $\mathrm{PM}_{2.5}$ in Beijing by positive matrix factorization, Atmos. Environ., 40, 1526-1537, doi:10.1016/j.atmosenv.2005.10.039, 2006.

Sun, J., Zhang, Q., Canagaratna, M. R., Zhang, Y., Ng, N. L., Sun, Y., Jayne, J. T., Zhang, X., Zhang, X., and Worsnop, D. R.: Highly time- and size-resolved characterization of submicron aerosol particles in Beijing using an Aerodyne Aerosol Mass Spectrometer, Atmos. Environ., 44, 131-140, 2010.

Sun, Y.: Long-term Measurements of Aerosol Particle Composition with an Aerosol Chemical Speciation Monitor in Megacity Beijing, China, AAAR 31st Annual Conference, Hyatt Regency Minneapolis, Minneapolis, Minnesota, 3UA.1, 2012.

Sun, Y., Zhuang, G., Tang, A., Wang, Y., and An, Z.: Chemical Characteristics of $\mathrm{PM}_{2.5}$ and $\mathrm{PM}_{10}$ in Haze-Fog Episodes in Beijing, Environ. Sci. Technol., 40, 3148-3155, 2006.

Sun, Y., Wang, Z., Dong, H., Yang, T., Li, J., Pan, X., Chen, P., and Jayne, J. T.: Characterization of summer organic and inorganic aerosols in Beijing, China with an Aerosol Chemical Speciation Monitor, Atmos. Environ., 51, 250-259, doi:10.1016/j.atmosenv.2012.01.013, 2012.

Sun, Y., Wang, Z., Fu, P., Jiang, Q., Yang, T., Li, J., and Ge, X.: The Impact of Relative Humidity on Aerosol Composition and Evolution Processes during Wintertime in Beijing, China, Atmos. Environ., submitted, 2013.

Sun, Y.-L., Zhang, Q., Schwab, J. J., Demerjian, K. L., Chen, W.N., Bae, M.-S., Hung, H.-M., Hogrefe, O., Frank, B., Rattigan, O. V., and Lin, Y.-C.: Characterization of the sources and processes of organic and inorganic aerosols in New York city with a high-resolution time-of-flight aerosol mass apectrometer, Atmos. Chem. Phys., 11, 1581-1602, doi:10.5194/acp-11-1581- 
2011, 2011.

Takegawa, N., Miyakawa, T., Kuwata, M., Kondo, Y., Zhao, Y., Han, S., Kita, K., Miyazaki, Y., Deng, Z., Xiao, R., Hu, M., van Pinxteren, D., Herrmann, H., Hofzumahaus, A., Holland, F., Wahner, A., Blake, D. R., Sugimoto, N., and Zhu, T.: Variability of submicron aerosol observed at a rural site in Beijing in the summer of 2006, J. Geophys. Res., 114, D00G05, doi:10.1029/2008jd010857, 2009.

Ulbrich, I. M., Canagaratna, M. R., Zhang, Q., Worsnop, D. R., and Jimenez, J. L.: Interpretation of organic components from Positive Matrix Factorization of aerosol mass spectrometric data, Atmos. Chem. Phys., 9, 2891-2918, doi:10.5194/acp-9-2891-2009, 2009.

Wang, X., Williams, B. J., Wang, X., Tang, Y., Huang, Y., Kong, L., Yang, X., and Biswas, P.: Characterization of organic aerosol produced during pulverized coal combustion in a drop tube furnace, Atmos. Chem. Phys. Discuss., 13, 3345-3377, doi:10.5194/acpd-13-3345-2013, 2013.

Watson, J. G.: Visibility: Science and regulation, J. Air Waste Manage. Assoc., 52, 628-713, 2002.

Wu, W. S. and Wang, T.: On the performance of a semi-continuous $\mathrm{PM}_{2.5}$ sulphate and nitrate instrument under high loadings of particulate and sulphur dioxide, Atmos. Environ., 41, 54425451, doi:10.1016/j.atmosenv.2007.02.025, 2007.

Yao, X., Chan, C. K., Fang, M., Cadle, S., Chan, T., Mulawa, P., He, $\mathrm{K}$., and Ye, B.: The water-soluble ionic composition of $\mathrm{PM}_{2.5}$ in Shanghai and Beijing, China, Atmos. Environ., 36, 4223-4234, doi:10.1016/s1352-2310(02)00342-4, 2002.

Yuan, Y., Liu, S., Castro, R., and Pan, X.: $\mathrm{PM}_{2.5}$ Monitoring and Mitigation in the Cities of China, Environ. Sci. Technol., 46, 3627-3628, doi:10.1021/es300984j, 2012.

Zhang, H., Wang, S., Hao, J., Wan, L., Jiang, J., Zhang, M., Mestl, H. E. S., Alnes, L. W. H., Aunan, K., and Mellouki, A. W.: Chemical and size characterization of particles emitted from the burning of coal and wood in rural households in Guizhou, China, Atmos. Environ., 51, 94-99, doi:10.1016/j.atmosenv.2012.01.042, 2012a.

Zhang, J. P., Zhu, T., Zhang, Q. H., Li, C. C., Shu, H. L., Ying, Y., Dai, Z. P., Wang, X., Liu, X. Y., Liang, A. M., Shen, H. X., and Yi, B. Q.: The impact of circulation patterns on regional transport pathways and air quality over Beijing and its surroundings, Atmos. Chem. Phys., 12, 5031-5053, doi:10.5194/acp-12-50312012, 2012b.
Zhang, Q. and Tie, X.: High solubility of SO2: evidence in an intensive fog event measured in the NCP region, China, Atmos. Chem. Phys. Discuss., 11, 2931-2947, doi:10.5194/acpd11-2931-2011, 2011.

Zhang, Q., Alfarra, M. R., Worsnop, D. R., Allan, J. D., Coe, H., Canagaratna, M. R., and Jimenez, J. L.: Deconvolution and quantification of hydrocarbon-like and oxygenated organic aerosols based on aerosol mass spectrometry, Environ. Sci. Technol., 39, 4938-4952, doi:4910.1021/es0485681, 2005.

Zhang, Q., Jimenez, J., Canagaratna, M., Ulbrich, I., Ng, N., Worsnop, D., and Sun, Y.: Understanding atmospheric organic aerosols via factor analysis of aerosol mass spectrometry: a review, Anal. Bioanal. Chem., 401, 3045-3067, doi:10.1007/s00216-011-5355-y, 2011.

Zhang, Q. H., Zhang, J. P., and Xue, H. W.: The challenge of improving visibility in Beijing, Atmos. Chem. Phys., 10, 78217827, doi:10.5194/acp-10-7821-2010, 2010.

Zhang, Y.: Characterization of sub-micron aerosol and its change processes in BIV (Beijing and its vicinity) region, $\mathrm{PhD}$, Meteorology, Chinese Academy of Meteorological Sciences, China Meteorological Administration, Beijing, 2011.

Zhang, Y., Schauer, J. J., Zhang, Y., Zeng, L., Wei, Y., Liu, Y., and Shao, M.: Characteristics of Particulate Carbon Emissions from Real-World Chinese Coal Combustion, Environ. Sci. Technol., 42, 5068-5073, 2008a.

Zhang, Y. H., Hu, M., Zhong, L. J., Wiedensohler, A., Liu, S. C., Andreae, M. O., Wang, W., and Fan, S. J.: Regional Integrated Experiments on Air Quality over Pearl River Delta 2004 (PRIDE-PRD2004): Overview, Atmos. Environ., 42, 6157-6173, doi:10.1016/j.atmosenv.2008.03.025, 2008b.

Zhao, X. J., Zhao, P. S., Xu, J., Meng, W., Pu, W. W., Dong, F., He, D., and Shi, Q. F.: Analysis of a winter regional haze event and its formation mechanism in the North China Plain, Atmos. Chem. Phys. Discuss., 13, 903-933, doi:10.5194/acpd-13-9032013, 2013.

Zheng, M., Salmon, L. G., Schauer, J. J., Zeng, L., Kiang, C. S., Zhang, Y., and Cass, G. R.: Seasonal trends in $\mathrm{PM}_{2.5}$ source contributions in Beijing, China, Atmos. Environ., 39, 3967-3976, doi:10.1016/j.atmosenv.2005.03.036, 2005. 